Contrarian Real Estate Investment in Some Asia Pacific Cities

\author{
By \\ Kwame Addae-Dapaah \\ Ho, Kim Hin/David \\ $\&$ \\ Chua, Yong Hua
}

Department of Real Estate, National University of Singapore.

Correspondence to:

\author{
Kwame Addae-Dapaah \\ Department of Real Estate \\ School of Design \& Environment \\ National University of Singapore \\ 4 Architecture Drive \\ Singapore 117566 \\ Telephone: ++ 6568743417 Fax: ++ 6567748684 \\ E-mail: rstka@nus.edu.sg
}

Published in Journal of Property Research, 24, no. 2 (Special Issue on Asian Real Estate Markets and Investments) (2007): 159-190. (United Kingdom). DOI: 10.1080/09599910701440156 


\title{
Contrarian Real Estate Investment in Some Asia Pacific Cities
}

\begin{abstract}
The profitability of contrarian investment strategy (i.e. investing in value stocks) is one of the most well-established empirical facts in the finance literature. It would appear, however, that the strategy has not been extended to real estate. Thus, the paper examines the contrarian investment strategy in relation to real estate so as to ascertain the comparative advantage(s) (in terms of performance) of "value" and "growth" property investments. It is found, after a case study of eleven cities in the Asia Pacific over the period 1994Q2 through 2004Q2, that contrarian real estate investment consistently outperformed growth property investment. The results of stochastic dominance test validate the relative superiority of "value" over "growth" property investment. This implies that fund managers who traditionally have been favoring prime (i.e. growth) property investment may have to reconsider their investment strategy if they want to maximize their return.
\end{abstract}

Keywords: contrarian investment strategy, value-growth spread, value properties, growth properties, stochastic dominance.

\section{Introduction}

The choice of an investment strategy is an important step in the decision-making process of fund managers and large institutional investors. As a result, growth stock investment strategy and value stock investment strategy have received a great deal of attention in the finance literature. The growth stock investment strategy is frequently associated with investments in "glamour" stocks that have relatively high price-to-earnings ratios (i.e. high gross income multiplier in real estate terms ${ }^{1}$ ). On the other hand, value stock 
investment strategy usually involves investing in "gloomy" stocks that characteristically have relatively low market prices in relation to earnings per share (EPS), cash flow per share, book value per share, or dividends per share (i.e. low gross income multiplier). They are often less popular stocks that have recently experienced low or negative growth rates in corporate earnings. Yet, studies have shown that investments in value stocks, commonly known as contrarian investment strategies, have outperformed growth stocks in major markets (see for example, Fama and French [1993, 1995, 1996, 1998], Capual et al. [1993], Haugen [1995], Arshanapali et al. [1998], Levis and Liodakis [2001] and Lakonishok et al. [1994]).

However, Jones (1993) reports that the profitability of contrarian portfolios is a pre-WW II phenomenon that has since largely disappeared. Kryzanowski and Zhang (1992) find that the Canadian stock market exhibits significant price inertia, which negates the relative superiority of contrarian investments. Moreover, Jedadeesh and Titman (1993), Rouwenhorst (1998 \& 1999) and Grundy and Martin (2001) conclude that a momentum strategy (which contrasts the contrarian strategy) is profitable. These contrary findings have been refuted in the extant literature (see for example, Bauman and Miller 1997]).

In view of the significance of the contrarian hypothesis in the finance literature and the relationship between finance and real estate, it is surprising the contrarian hypothesis can hardly be found in the extant real estate literature. Thus, the motivation of the paper is to bridge this gap in the extant real estate literature in an attempt to put it on the real estate research agenda to promote discussion on the issue.

In view of the overwhelming evidence in support of the superior performance of contrarian investment in the finance literature, there appears to be a prima facie case for expecting contrarian real estate investment to do likewise (Addae-Dapaah et al. (2002)). Growth stock is analogous to prime properties as both have relatively low earnings-toprice ratio (i.e. low initial yield - see Tse, 2002) and investors in both investment media pin their hopes on a relatively high potential price or capital appreciation. Similarly, value stock that provides high income is comparable to high income-producing properties 
such as lower grade properties and properties in secondary locations. In relation to real property, the contrarian strategy implies that value properties with high running yield could outperform growth properties with low running yield. Thus, the objectives of the study are:

i) to ascertain the comparative advantage(s), in terms of performance, of contrarian real estate investment;

ii) to evaluate the relative riskiness of value properties and growth properties;

iii) to establish whether excessive extrapolation and expectational errors characterize growth and value strategies.

In view of this, the next section provides a brief review of the finance literature on the contrarian investment strategy after which, a specific set of research hypotheses are formulated. This is followed by a discussion on data management and sourcing, and the contrarian strategy model. The next section is devoted to the empirical model estimation which is followed by a post-model estimation. The last section deals with concluding remarks.

\section{Literature Review}

Dreman (1982) defines a contrarian as an investor who goes against the "grain". Hence, contrarian investment strategy simply refers to investment in securities on which other investors have turned their backs. It covers various investment strategies based on buying/selling stocks that are priced low/high relative to accounting measures of performance - earnings-to-price ratios $(\mathrm{E} / \mathrm{P})$, cash flow-to-price ratio $(\mathrm{C} / \mathrm{P})$ and book value-to-price ratio $(\mathrm{B} / \mathrm{P})$ - as well strategies based on low/high measures of earning per share (EPS) growth (Capual, 1993). In simple terms, the contrarian investment strategy refers to the value/growth stock paradigm.

While there is substantial empirical evidence supporting the efficient market hypothesis that security prices provide unbiased estimates of the underlying values, many still question its validity. Smidt (1968) argues that one potential source of market inefficiency 
is inappropriate market responses to information. The inappropriate responses to information implicit in Price-Earnings (P/E) ratios may be indicators of future investment performance of a security. Proponents of this price-ratio hypothesis claim that low $\mathrm{P} / \mathrm{E}$ securities tend to outperform high P/E stocks (Williamson, 1970). Basu (1977), Jaffe et al. (1989), Fama and French (1992, 1998), Davis (1994), Lakonishok et al. (1994), Bauman et al. (1998), and Chan and Lakonishok (2004) show a positive relationship between earnings yield and equity returns. However, as a result of the noisy nature of earnings (i.e. the category of stocks with low E/P include also stocks that have temporarily depressed earnings), value strategies based on E/P give narrower spreads compared to other simple value strategies (Chan and Lakonishok (2004)). Furthermore, in view of the noise in reported earnings that results from Japanese accounting standards (i.e. distortions in the earnings induced by accelerated depreciation allowances), Chan et al. (1991) find no evidence of a strong positive earnings yield effect after controlling for the other fundamental variables.

Rosenberg et al. (1985) show that stocks with high Book Value relative to Market Value of equity (BV/MV) outperform the market. Further studies, e.g. Chan et al. (1991) and Fama and French (1992), confirm and extend these results. In view of the highly influential paper by Fama and French (1992), academics (e.g. Capaul et al., 1993; Davis, 1994; Lakonishok et al., 1994; La Porta et al., 1997; Fama and French, 1998; Bauman et al., 1998 and 2001; Chan et al., 2000; and Chan and Lakonishok, 2004) have shifted their attention to the ratio of $\mathrm{BV} / \mathrm{MV}$ as one of the leading explanatory variables for the crosssection of average stock returns.

Although BV/MV has garnered the lion's share of attention as an indicator of valuegrowth orientation, it is by no means an ideal measure (Chan and Lakonishok (2004)). $\mathrm{BV} / \mathrm{MV}$ is not a 'clean' variable uniquely associated with economically interpretable characteristics of the firm (Lakonishok et al. (1994)). Many different factors are reflected in this ratio. A low BV/MV may describe a company with several intangible assets that are not reflected in accounting book value. A low BV/MV can also describe a company with attractive growth opportunities that do not enter the computation of book value but do enter the market price. A stock whose risk is low and future cash flows are discounted 
at a low rate would have a low BV/MV as well. Finally, a low BV/MV may be reminiscent of an overvalued glamour stock.

The shortcomings of accounting earnings have motivated a number of papers to explore the relationship between cash flow yields and stock returns. High Cash Flow to Price $\mathrm{CF} / \mathrm{P}$ ) stocks are identified as value stocks because their prices are low per dollar of cash flow, or the growth rate of their cash flows is expected to be low. Chan et al. (1991), Davis (1994), Lakonishok et al. (1994), Bauman et al. (1998), Fama and French (1998), and Chan and Lakonishok (2004) show that a high ratio of CF/P predicts higher returns. This is consistent with the idea that measuring the market's expectations of future growth more directly gives rise to better value strategies (La Porta (1996)).

To proxy for the market's expectations of future growth, Fama and French (1998) and Bauman et al. (1998) also use ratio of Dividends to Price (D/P). Firms with higher ratios have lower expected growth and are considered to be value stocks. They show that the performance of the value stocks based on dividend yields is quantitatively similar to the performance based on the prior categorizations (i.e. P/E, BV/MV and CF/P). Finally, rather by expectations of future growth to operationalize the notions of glamour and value, Davis (1994) and Lakonishok et al. (1994) classify stocks based on past growth. In particular, they measure past growth by Growth in Sales (GS) and the spread in abnormal returns is sizeable.

To the extent that the different valuation indicators of value-growth orientation are not highly correlated, a strategy based on information from several valuation measures may enhance portfolio performance. Lakonishok et al. (1994) explore sophiscated twodimensional versions of simple value strategies. According to the two-way classification, value stocks are defined as those that have shown poor growth in sales, earnings and cash flow in the past, and are expected by the market to continue growing slowly. Expected performance is measured by multiples of price to current earnings and cash flow. La Porta et al. (1997) form portfolios on the basis of a two-way classification based on past GS and CF/P introduced by Lakonishok et al. (1994). Using robust regression methods, Chan and Lakonishok (2004) estimate cross-sectional models that predicted future yearly returns from beginning-year values of the $\mathrm{BV} / \mathrm{MV}, \mathrm{CF} / \mathrm{P}, \mathrm{E} / \mathrm{P}$ and the sales to price ratio. 
The use of the multiple measures in the composite indicators boosts the performance of the value strategy.

Jegadeesh and Titman (1993) controvert the above findings by showing that a momentum strategy (i.e. buying/selling past winners/losers) generates better returns. This conclusion has been concurred by Rouwenhorst (1998 \& 1999) and Grundy and Martin (2001). Jones (1993) reports that the profitability of contrarian portfolios is a pre-WW II phenomenon that has since largely disappeared. However, this has been refuted by later

studies which include post-war data. Also, Kryzanowski and Zhang (1992) suggest that positive profits resulting from the use of the contrarian investment strategy are limited to the U.S. stock market. When applied to the Canadian stock market, the DeBondt and Thaler (1985) do not produce favorable results. Instead of finding significant price reversals, Kryzanowski and Zhang (1992) find that the Canadian stock market exhibits significant price continuation behavior, which does not support contrarian investments. This is also refuted by later studies that conclude mean-reversion tendency (see for example, Bauman and Miller [1997]).

Based on the accumulated weight of the evidence from past studies, the academic community agrees that value investment strategies, on average, outperform growth investment strategies. The only polemical issue about the contrarian strategy is the rationale for its superior performance. Competing explanations include risk premiums (Fama and French, 1993, 1995, 1996), systematic errors in investors' expectations and analysts' forecasts - i.e. naïve investor expectations of future growth and research design induced bias (see for example, La Porta et al., 1997; Bauman \& Miller, 1997; La Porta, 1996; Dechow \& Sloan, 1997; Lakonishok et al., 1994; Lo and MacKinlay, 1990; Kothari et al., 1995) and the existence of market frictions (Amihud and Mendelson, 1986) .

\subsection{Rationale for the Superior Performance of the Contrarian Strategy}

The traditional view, led by Fama and French $(1993,1995,1996)$, is that the superior performance is a function of contrarian investment being relatively risky (see also Chan, 1988; Ball and Kothari, 1989). However, Lakonishok et al. (1994), MacKinley (1995), La Porta et al. (1995, 1997), Daniel and Titman (1996) have found that risk-based 
explanations do not provide a credible rationale for the observed return behaviour (see Jaffe et al. (1989), Chan et al. (1991), Chopra et al. (1992), Capaul et al. (1993), Bauman et al. (1998, 2001), and Chan and Lakonishok (2004)).

The behavioural finance paradigm recognizes psychological influences on human decision-making in which experts (in this case, investors) tend to focus on, and overuse, predictors of limited validity (i.e., earnings trend in the recent past) in making forecasts. In view of systematic errors in investors' expectations and analysts' forecasts, it has been argued that a significant portion of value stocks' superior performance is attributable to earning surprises (see De Bondt and Thaler, 1985; Lakonishok et al., 1994; La Porta, 1996; Chan et al., 2000, 2003). According to Dreman and Berry (1995) and Levis and Liodakis (2001), positive and negative earnings surprises have an asymmetrical effect on the returns of value and growth stocks. Positive earning surprises have a disproportionately large positive impact on value stocks while negative surprises have a relatively benign effect on such stocks (see also Bauman and Miller, 1997).

Furthermore, analysts and institutional investors may have their own reasons for gravitating toward growth stocks. Analysts have self-interest in recommending successful stocks to generate trading commissions and more investment banking business. Moreover, growth stocks are typically in 'promising' industries, and are thus easier to promote in terms of analyst reports and media coverage (Bhushan, 1989; and Jegadeesh et al., 2004). These considerations play into the career concerns of institutional money managers (Lakonishok et al., 1994). Another important factor is that most investors have shorter time horizons than are required for value strategies to consistently pay off (De Long et al., 1990; Shleifer and Vishny, 1990). The result of all these considerations is that value stocks/glamour stocks become under-priced/overpriced relative to their fundamentals. Due to the limits of arbitrage (Shleifer and Vishny (1997)), the mispricing patterns can persist over long periods of time. 
A third hypothesis that has been postulated for the superiority of the contrarian strategy is that the reported cross-sectional return differences is an artifact of the research design and the database used to conduct the study (Black, 1993; Kothari et al., 1995). Thus, the abnormal returns would be reduced or vanish if different methodology and data were used. Such researchers argue that the superior returns are the result of survivor biases in the selection of firms (Banz and Breen, 1986), look-ahead bias (Banz and Breen, 1986), and a collective data-snooping exercise by many researchers sifting through the same data (Lo and MacKinlay, 1990). Other problems include model specification (i.e. the appropriateness of parametric analysis and single factor capital asset pricing model) and misestimation of systematic risk (Mun et al. [2001], Badrinath and Omesh [2001]). Finally, the database is limited to a relatively short sample period (Davis, 1994). The data-snooping explanation has been controverted by Lakonishok et al. (1994), Davis (1994, 1996), Fama and French (1998), Bauman and Conover (1999), Bauman et al., (2001), and Chan and Lakonishok (2004) who used databases that are free of survivorship bias and/or fresh data that previously have not been used for such analysis to confirm the superior performance of value strategy. Mun et al. (2001:635) refute the model specification criticism to conclude that the result of nonparametric analysis "is a distilled and pure Contrarian Strategy effect" - The parametric analysis confirms contrarian superiority although it provides a more conservative yield estimate of excess returns than parametric estimates. Similarly, Badrinath and Omesh (2001) conclude that misestimation of systematic risk cannot explain the abnormal profitability of the contrarian strategy (see Gregory et al. [2003]). Thus, the superiority of the contrarian strategy is not a function of the mathematical/statistical models used for the analysis.

Furthermore, two features of value investing distinguish it from other possible anomalies. According to Chan and Lakonishok (2004), many apparent violations of the efficient market hypothesis, such as day-of-the-week patterns in stock returns, lack a convincing logical basis and the anomalous pattern is merely a statistical fluke that has been uncovered through data mining. The value premium, however, can be tied to ingrained patterns of investor behavior or the incentives of professional investment managers.

In view of the analogy between value stock and high income producing property (henceforth called value property ${ }^{2}$ ), the features of the contrarian investment strategy may apply to property investment. Therefore, it is hypothesized that: 
a) $\quad \mathrm{H}_{\mathrm{o}}$ Return value properties $=$ Return growth properties

$\mathrm{H}_{\mathrm{a}:}$ Return value properties $>$ Return growth properties

b) $\quad \mathrm{H}_{\mathrm{o}}$ Risk value properties $=$ Risk growth properties

$\mathrm{H}_{\mathrm{a}}$ Risk value properties $\neq$ Risk growth properties

The first hypothesis will be operationalised through statistical testing of the significance of the value-growth spread. If the spread is found to be statistically significant, the second hypothesis will be used to ascertain whether the superior performance of value property is a function of it having a higher risk than growth property.

\section{Data Sourcing and Management}

A growth real estate investor prefers properties with a low initial yield which is more than compensated by a prospect of high future capital or rental growth to properties with high initial yield. The investor chooses to exchange immediate cash flows for higher future cash flows that are worth more at the date of the purchase, depending on the investor's opportunity cost of capital. On the other hand, a value property investor prefers to receive a high initial yield rather than to wait for future income or capital growth (see Marcato [2004]). The paper uses the Jones Lang Lasalle Real Estate Intelligence ServiceAsia (JLL REIS-Asia) and the Property Council of New Zealand databases from 1994Q2 to 2004Q2 to categorize twenty-one Pacific Rim office property sub-markets into value/growth sub-markets on the bases of their initial yields (Table1), i.e. E/P ratio.

JLL REIS-Asia dataset consists of ex post quarterly (since 1994) and ex-ante annual (forecasts for the next 4 years) capital and rental values of prime commercial properties for 16 Asia real estate market sectors (i.e. eight retail sectors and eight office sectors). The capital and rental values of commercial real estate assets (office and retail) in the eight cities are based on a basket of 30 prime commercial buildings per sector in each city. Rental values are based on actual rents while the capital values are based on transactions and estimated valuations. The JLL REIS-Asia ex ante data are derived from JLL's proprietary quantitative forecasting and the consensus views of the JLL network of branch offices in Asian cities, namely: Singapore (the Raffles Place CBD), Beijing, Shanghai, Hong Kong (the Central \& major business districts), Bangkok, Manila (Makati 
CBD), Kuala Lumpur and Jakarta ${ }^{3}$. The criteria for selecting investment grade offices for the dataset are the same for all the markets in the sample. Thus, the dataset provides a basis for comparing like with like. Similarly, the data from the Property Council of New Zealand are based on market rentals and valuations. The quality of this data is attested by the fact that it has been currently subsumed by the IPD. Both datasets are extensively used by researchers in Singapore and New Zealand. The only caveat about the use of two different datasets is that one cannot guarantee that the quality of both datasets is the same. However, both datasets are of very good quality to provide credible results.

The other accounting measures of classification are not employed in the analyses because of the dearth of data. Moreover, the extant literature shows that the results of studies based on the other accounting measures of classification confirm, rather than contradict, the results of studies based on E/P (i.e. initial yield) classification. Thus, the inability to use these accounting measures (due to lack of data) is not a major handicap.

\section{Tahle 1}

To facilitate cross-market comparisons, the initial yields are measured in U.S. dollars. At the end of each quarter between 1994Q2 and 2004Q2, quartile portfolios are formed on the basis of the end-of-previous-quarter's initial yield. One-fourth of the sample with the highest initial yields is treated as the value properties $\left(\mathrm{V}_{\mathrm{p}}\right)$ while the one-fourth with the lowest initial yields is considered to be growth properties $\left(G_{p}\right)$. Quartile 2 (denoted as value2 in Figure 1) has the properties with the second highest yields, while Quartile 3 (denoted as growth2 in Exhibit 8) has the properties with the second lowest yields. Each quartile is treated as a portfolio composed of equally weighted properties. This system of classification follows the classification used in the finance literature (see for example: Chan et al. (1991) and Bauman et al. (1998, 2001)).

The grouping of the twenty-one office property markets into quartile portfolios is followed by an investigation of the relative performances of the value and growth properties. If there is evidence of a value premium in the Pacific Rim office property markets, the paper will discuss the underlying reasons behind the relative superiority of value properties. 


\section{The Contrarian Strategy Model}

The performances of both the value and growth properties are compared on a 1-quarter, 3-year, 5-year, and entire holding-period (of up to 40 quarters) horizons. In the evaluation of the relative superiority of the performance of quartile portfolios, periodic (i.e. quarterby-quarter) return measure is used. The periodic returns are quantified as simple holding period returns. For the longer investment horizon (i.e. 3-year, 5-year and entire holdingperiod), the simple holding period returns are calculated for each quarter and compounded to obtain the multi-year holding-period returns as defined in equation (1).

$$
r_{t}=\left[\left(1+r_{1}\right)\left(1+r_{2}\right) \ldots\left(1+r_{m}\right)\right]-1 \text { (Levy, 1999). }
$$

Where

$$
\begin{array}{ll}
r_{1}, r_{2} \ldots r_{m} & =\text { return for each quarter of the period } m . \\
m & =\text { number of quarters for the holding period. }
\end{array}
$$

Compared to simply adding the returns for all quarters of a given period, equation (1) is more accurate (Sharpe et al., 1998). The periodic quartile returns for each holding- period horizon are averaged across the full period of study to determine the time-weighted average return. Arithmetic mean is most widely used in forecasts of future expectations and in portfolio analysis (Geltner and Miller, 2001). Each value-growth spread (i.e. value premium) is then computed by subtracting the mean return on a growth quartile from that on the corresponding value quartile.

The pooled-variance $t$ test and separate-variance $t$ test are then used to determine whether there is a significant difference between the means of the value and growth properties. If the p-value is smaller than the conventional levels of significance (i.e. 0.05 and 0.10 ), the null hypothesis that the two means are equal will be rejected:

$$
\begin{aligned}
& H_{0}: \mu_{\text {value }}=\mu_{\text {growth }} \\
& H_{1}: \mu_{\text {value }} \neq \mu_{\text {growth }}
\end{aligned}
$$

The next step is to determine whether any difference in returns is a function of variation in risk, using a more direct evaluation of the risk-based explanation that focuses on the performance of the value and growth properties in 'bad' states of the world. Traditional 
measures of risk such as standard deviation of returns, risk-to-return ratio (i.e. coefficient of variation $-\mathrm{CV}$ ) and return-to-risk ratio will be utilized.

The Levene's Test is used to test the equality of the variances for the value and growth properties:

$$
\begin{aligned}
& H_{0}: \sigma_{\text {value }}^{2}=\sigma^{2}{ }_{\text {growth }} \\
& H_{1}: \sigma_{\text {value }}^{2} \neq \sigma_{\text {growth }}^{2}
\end{aligned}
$$

\subsection{Performance in 'Bad' States of the World}

According to Lakonishok et al. (1994), value strategies would be fundamentally riskier than glamour strategies if:

i) they under-perform glamour strategies in some states of the world, and

ii) those are on average 'bad' states of the world, in which the marginal utility of wealth is high, making value strategies unattractive to risk-averse investors.

Periods of severe stock market declines are used as a proxy for 'bad' states of the world. This is because they generally correspond to periods when aggregate wealth is low and thus the utility of an extra dollar is high. The approach of examining property performance during down markets also corresponds to the notion of downside risk that has gained popularity in the investment community (Chan and Lakonishok, 2004). If the above tests confirm the superiority of value properties, stochastic dominance will be used to ascertain the optimality of the value property investment strategy.

\section{Stochastic Dominance}

The most widely known and applied efficiency criterion for evaluating investments is the mean-variance model. An alternative approach is the stochastic dominance $(S D)$ analysis, which has been employed in various areas of economics, finance and statistics (Levy, 1992; Alkhazali, 2002; Kjetsaa and Kieff, 2003). The efficacy and applicability of $S D$ analysis, and its relative advantages over the mean-variance approach have been discussed and proven by several researchers including Hanoch and Levy (1969), Hadar and Russell (1969), Rothschild and Stiglitz (1970), Whitmore, 1970, Levy (1992), Al-khazali (2002) and Barrett and Donald (2003). According to Taylor and Yodder (1999), SD is a theoretically unimpeachable general model of portfolio choice that maximizes expected utility. It uses the entire probability density 
function rather than simply summarizing a distribution's features as given by its statistical moments.

\subsection{Stochastic Dominance Criteria}

The SD rules are normally specified as first, second, and third degree $S D$ criteria denoted by FSD, SSD, and TSD respectively (see Levy, 1992; Barrett and Donald, 2003; Barucci, 2003). There is also the nth degree $S D$. Given that $F$ and $G$ are the cumulative distribution functions of two mutually exclusive risky options $X$ and $Y, F$ dominates $G(F D G)$ by $F S D, S S D$, and $T S D$, denoted by $F D_{1} G, F D_{2} G$, and $F D_{3} G$, respectively, if and only if,

$$
\begin{array}{ll}
F(X) \leq G(X) & \text { for all } X(F S D) \\
\int_{-\infty}^{x}[G(t)-F(t)] d t \geq 0 & \text { for all } X(S S D) \\
\int_{-\infty}^{x} \int_{-\infty}^{v}[G(t)-F(t)] d t d v \geq 0 & \text { for all } X, \text { and } \\
E_{F}(X) \geq E_{G}(X)(T S D) &
\end{array}
$$

The FSD (also referred to as the General Efficiency Criterion - Levy and Sarnat, 1972) assumes that all investors prefer more wealth to less regardless of their attitude towards risk. The SSD is based on the economic notion that investors are risk averse while the TSD posits that investors exhibit decreasing absolute risk aversion (Kjetsaa and Kieff, 2003). A higher degree $S D$ is required only if the preceding lower degree $S D$ does not conclusively resolve the optimal choice problem. Thus, if $F D_{1} G$, then for all values of $x, F(x) \leq G(x)$ or $G(x)-F(x) \geq 0$. Since the expression cannot be negative, it follows that for all values of $x$, the following must also hold:

$$
\int_{-\infty}^{x}[G(t)-F(t)] d t \geq 0 ; \text { that is, } F D_{2} G \text { (Levy and Sarnat, 1972) }
$$

Furthermore, the $S D$ rules and the relevant class of preferences $U_{i}$ are related in the following way:

FSD: $F(X) \leq G(X) \forall X \Leftarrow \Rightarrow E_{F} U(X) \geq E_{G} U(X) \quad \forall u \in U_{1}$,

SSD: $\int_{-\infty}^{x} F(t) d t \geq \int_{-\infty}^{x} G(t) d t \forall X \Leftarrow \Rightarrow E_{F} U(X) \geq E_{G} U(X) \quad \forall u \in U_{2}$,

TSD: $\int_{-\infty}^{x} \int_{-\infty}^{v} F(t) d t d v \geq \int_{-\infty}^{x} \int_{-\infty}^{x} G(t) d t d v \forall X \Leftarrow \Rightarrow E_{F} U(X) \geq E_{G} U(X)$

$$
\forall u \in U_{3} \text {, and }
$$




$$
E_{F}(X) \geq E_{G}(X),
$$

where $U_{i}=$ utility function class $(i=1,2,3)$

$U_{1}$ includes all $u$ with $u^{\prime} \geq 0$;

$U_{2}$ includes all $u$ with $u^{\prime} \geq 0$ and $u^{\prime \prime} \leq 0$; and

$U_{3}$ includes all $u$ with $u^{\prime} \geq 0, u^{\prime \prime} \leq 0$ and $u^{\prime \prime \prime} \geq 0$.

In other words, a lower degree $S D$ is embedded in a higher degree $S D$. The economic interpretation of the above rules for the family of all concave utility functions is that their fulfilment implies that $E_{F} U(x)>E_{G} U(x)$ and $E_{F}(x)>E_{G}(x)$; i.e. the expected utility and return of the preferred option must be greater than the expected utility and return of the dominated option.

\section{Empirical Model Estimation - A Test of the Extrapolation Model}

Following the evaluation of the risk characteristics of the value and growth properties, the final task is to investigate the relationship between the past, the forecasted, and the actual future growth rates. This relationship is largely consistent with the predictions of the extrapolation model. The essence of extrapolation is that investors are excessively optimistic about growth properties and excessively pessimistic about value properties. A direct test of extrapolation (Lakonishok et al. (1994)), then, is to look directly at the actual future rental income and capital growth rates of value and growth properties, and compare them to:

a) past growth rates and

b) expected growth rates as implied by the initial yields.

Table 2 presents the descriptive statistics of the initial yields for each quartile. Over the full period of study from 1994Q2 to 2004Q2, the median rental-to-price ratio for the value quartile $(9.88 \%)$ was substantially higher than the growth quartile $(3.97 \%)$. The median rental-to-price ratio ranges from $7.42 \%$ to $22.32 \%$ for the value properties, and $1.86 \%$ to $5.11 \%$ for the growth properties.

According to the initial yield classification (Table 1), office properties in locations such as Auckland CBD, Hong Kong Wanchai, Raffles Place, Shenton Way and Tokyo CBD 
are often classified as glamour properties while office properties in Bangkok CBD, Jakarta CBD, Makati CBD, Seoul and Shanghai Puxi are often associated with value properties.

\section{Table 2}

\subsection{Performance of the Contrarian Strategy}

The returns and value-growth spread for the 1-quarter holding period are presented in Table 3. The high initial yield (i.e. value) properties enjoyed positive returns in 40 out of 40 quarters while the low initial yield (i.e. growth) properties suffered negative returns in 11 out of the 40 quarters. Value properties also outperformed the growth properties throughout the 40 quarters, with the value-growth spread ranging from $0.81 \%$ to $17.58 \%$ per quarter. The mean quarterly returns for value and growth properties were $10.94 \%$ and $2.41 \%$ respectively during the period - a mean quarterly value premium of $8.52 \%$.

Table 3

The long-horizon returns (of up to 40 quarters) are presented in Tables 4 to 6 . Because of various market microstructure issues as well as execution costs, the long-horizon returns are closer to what investors can actually expect.

\section{Table 4}

Exhibit 4 demonstrates the superiority of the performance of value portfolios over growth-property portfolios. The mean 3-year holding period return for value/growth portfolios is $165.24 \% / 26.59 \%$. The value premium ranges from $40.70 \%$ to $303.76 \%$.

These figures are equivalent to an annualized value premium of between $3.44 \%$ and $6.72 \%$. On the average, anyone who invested in value portfolios would have been $138.65 \%$ richer per 3-year holding period than anyone who invested in growth portfolios. The superior performance of value portfolios is further attested by the results for the 5year and the longer-term holding periods presented in Tables 5 and 6.

\section{Tables 5 \& 6.}

The mean 5-year holding period return for value/growth portfolios is $259.71 \% / 45.17 \%$ (Table 5). The value premium for the 5-year holding period ranges from $133.77 \%$ to $330.70 \%$ - an annualized value premium of $2.66 \%$ to $3.19 \%$. These results are consistent 
with Arshanapalli et al. (1998). Similarly, the mean returns for the longer holding periods (Table 6) are $530.37 \%$ (for value portfolios) and $67.03 \%$ (for growth portfolios). The value premium increases with the length of the holding period (Table 6). Anyone who invested in the value portfolios would have been $214.54 \%$ richer per 5-year holding period than his counterpart who invested in the growth portfolios. Similarly, an investor in the value portfolios would have been, on average, $695.02 \%$ wealthier than an investor in the growth portfolios over the longer holding periods. The differences between the mean returns for both portfolios are statistically significant at the 0.05 level (Table 7).

\section{Table 7}

The relative superiority of the value portfolio is confirmed by the results of stochastic dominance test presented in Figures 1a-d.

\section{Figures 1a-d}

Figure 1a shows that $\mathrm{V}_{\mathrm{p}} \mathrm{D}_{1} \mathrm{G}_{\mathrm{p}}, \mathrm{V}_{\mathrm{p}} \mathrm{D}_{2} \mathrm{G}_{2}$ while $\mathrm{V}_{2} \mathrm{D}_{2} \mathrm{G}_{2}$. Similarly, Figures $1 \mathrm{~b}$-d clearly reveal that the value portfolio stochastically dominates the other three portfolios in the first order - i.e. the value portfolio is the most efficient (and therefore the optimal) choice. This implies that value portfolio stochastically dominates growth portfolio in the first, second and third order. It provides a higher probability of receiving a return greater than or equal to a given holding period return than the growth portfolio. For example, Exhibit $8 \mathrm{c}$ shows that there was a $60 \%$ and $0 \%$ probability that the 5 -year holding period return for value and growth portfolios respectively was greater than or equal to $200 \%$. In other words, the value portfolio statistically prognosticated a higher probability of success. Thus, value portfolio investment should have been preferable to both risk averters and risk lovers (Kjetsaa and Kieff, 2003; Levy and Sarnat, 1972).

\subsection{Are Contrarian Strategies Risky?}

Two alternative theories have been proposed to explain the superior performance of value strategies. The first theory states that value strategies expose investors to greater systematic risk (i.e. higher return is a reward for higher risk) while the second theory says that value strategies exploit the mistakes of naïve investors to provide superior returns.

In addressing the first explanation, the paper examines the consistency of the performance of the value and growth strategies over time to ascertain the number of times 
that "value" underperformed growth strategy. The paper then checks whether the times that "value" under-performed "growth" were times of severe market declines, i.e. "bad" states of the world, in which the marginal utility of consumption is high. If the value strategy is fundamentally riskier, it should under-perform the growth strategy during undesirable states of the world (Lakonishok et al., 1994). Finally, traditional measures of risk (i.e. standard deviation) and risk-adjusted performance indicator (i.e. coefficient of variation) are used to compare "value" and growth strategies.

The results in Tables 3-6 show that the value strategy never under-performed the growth strategy in any holding period. In other words, there is no underperformance of the value portfolio to be associated with very bad states of the world as defined by some pay-off relevant factor.

Some evidence on the performance of the value and growth properties in extreme down markets can be gleaned from Table $8 \mathrm{a}$ and 8b. Using the Datastream Indices (Pacific Basin Real Estate), the performance of the value and growth properties in the worst quarters for the stock market is compared (see Figure 2). The 40 quarterly data are classified into 4 states of the world: the worst 10 quarters (W10), the next worst 10 quarters (NW10), the best 10 quarters (B10), and the next best 10 quarters (NB10) Exhibit $10 \mathrm{~b}$. The quarterly returns on the various growth and value properties are then matched with the changes in the stock return. The average difference in returns between value and growth properties in each state is reported together with the corresponding tstatistics for the test that the difference of returns is equal to zero (Table 8b), i.e.

$$
\begin{aligned}
& H_{o}: \mu_{\text {value }}-\mu_{\text {growth }}=0 \\
& H_{o}: \mu_{\text {value }}-\mu_{\text {growth }} \neq 0
\end{aligned}
$$

\section{Figure 2 and Tables $8 a$ \& $8 b$}

An examination of Table $8 \mathrm{~b}$ shows that the value strategy was not fundamentally riskier than the growth strategy. Value strategy did notably better than growth strategy in each of the 4 states of the world. In addition, as the p-value is less than 0.01 in each of the 4 states of the world, the paper rejects the null hypothesis and concludes that there is statistical difference between the means of the two populations (i.e. value and growth properties). The value portfolio provided an average return of $10.83 \%$ per quarter in the 
worst 10 quarters, whereas the growth portfolio provided $1.14 \%$ average quarterly return. Similarly, the value portfolio, on average, outperformed the growth portfolio by $8.16 \%$ per quarter in the next worst 10 quarters in which the index declined. In the very best quarters, the value strategy again outperformed the growth strategy by $8.09 \%$ (see Table $8 b)$. If anything, the superior performance of the value strategies was skewed towards negative market return months rather than positive market return months.

Thus, it is implausible to conclude from this that the value strategy did particularly badly in the worst months for the stock market when the marginal utility of consumption was especially high. According to Lakonishok et al. (1994), performance in extreme bad states is often the last refuge of those claiming that a return strategy must be riskier, even when conventional measures of risk such as the beta and standard deviation do not show it. The evidence indicates that there are no significant traces of a conventional asset pricing equilibrium in which the higher returns on the value strategy are compensation for higher systematic risk.

The volatility of the portfolios' returns during the period of study is shown at the bottom of Tables 3 to 6 . The results show that value portfolios recorded higher standard deviation of returns than growth portfolios for all the holding periods under consideration. The total risk, as measured by standard deviation, for the value portfolios was 4.62 percent, 93.88 percent, 85.17 percent and 471.80 percent respectively for the above holding periods. These are higher than the corresponding total risk of 4.48 percent, 36.42 percent, 44.36 percent and 66.48 percent for the growth portfolios. According to the results presented in Table 9, the higher value portfolio standard deviations for the 3year, 5-year and entire holding-period horizons are statistically and significantly different, at the 0.01 level, from those of the growth properties.

\section{Table 9}

However, standard deviation is not a good measure for comparison as the mean returns are different. In such a situation, the coefficient of variation provides a simple relative risk measure that may be used to compare portfolios having returns with different means and variances. Table 10 presents the average coefficient of variations and return-risk ratios for the various holding-periods. 


\section{Table 10}

The evidence show that the value portfolios are safer (as measured by $\mathrm{CV}$ ) than the growth portfolios (Table 10). Furthermore, since value portfolio stochastically dominates growth portfolio, the latter is riskier than the former (Biswas, 1997). Hence, a risk model based on differences in standard deviation cannot also explain the superior returns on value properties.

\section{Post-Model Estimation - A Test of the Extrapolation Model}

In this section, the paper seeks to provide direct evidence that excessive extrapolation and expectational errors indeed characterize growth and value strategies. Table 11 presents some descriptive characteristics for the growth and value portfolios with respect to their initial yields, past growth rates, and future growth rates. Panel A reveals that the value portfolio had a much higher ratio of rental income to price. This ratio is interpreted in terms of lower expected growth rates for value properties. Panel B shows that, using several measures of past growth, including rental income and capital value, the return for growth properties grew faster than value properties over the 5 years before portfolio formulation. Panel $\mathrm{C}$ shows that over the 5 post-formulation years, the relative growth of rental income and capital value for growth properties was much less impressive.

\section{Table 11}

To interpret differences in initial yield in terms of expected rental growth rates, recall that the Gordon's formula (Gordon and Shapiro (1956)) can be rewritten as $k_{p}\left(\equiv \frac{I}{P}\right)=R_{N}-g_{p}=d$, where $k_{p}$ is the initial yield for property, $I$ is the current rental income, $P$ is the market price, $R_{N}$ is the required nominal return, and $\left(g_{p}-d\right)$ is the rental growth for actual, depreciating properties. Taken literally, these formulae imply that, holding discount rates constant, the differences in expected rental growth rates can be directly calculated based on differences in initial yields. Since the assumptions behind these simple formulae are restrictive (e.g. constant growth rates, etc.), the paper does not calculate exact estimates of the differences in expected rental growth rates between value 
and growth portfolios. Instead, the paper asks whether the large differences in initial yields between value and growth properties can be justified by the differences in future rental growth rates.

The past growth for glamour (i.e. growth) properties by any measure should be much faster than that of value properties. For example, over the 5 years before portfolio formation (i.e. 1994Q3 to 1999Q2), the average quarterly growth rate for rental income for the glamour portfolio was $1.35 \%$ compared to $-2.70 \%$ for the value portfolio (see Panel B of Table 11).

A dollar invested in the value portfolio in 2 nd quarter 1999 was a claim to 10.05 cents of the then existing rental income while a dollar invested in the growth portfolio was a claim to only 4 cents of the rental income (Panel A of Table 11). Ignoring any difference in required rates of return, the large difference in initial yields have to be justified by an expectation of very different growth rates over a long period of time. Under the assumption that discount rates were approximately equal, the expected rental income for the growth portfolio must be higher than the value portfolio at some future date. Accordingly, investors would like to know the number of quarters it would take for the rental income per dollar invested in the growth portfolio (0.0400) to equal to the rental income of the value portfolio (0.1005), assuming that the differences in past rental income growth rates were to persist (i.e. $1.35 \%$ versus $-2.70 \%$ ). The answer turns out to be approximately 23 years (see Table 12). Note that this equality is based on a flow basis not on a present-value basis. Equality on a present-value analysis would require an even longer time period over which glamour properties should experience superior growth.

\section{Table 12}

These implied growth expectations to the actual rental growth experienced by the glamour and value portfolios can now be compared. Over the first 5 years after formation, the average rental income for the growth portfolios declined by $0.06 \%$ per quarter versus $1.52 \%$ for the value portfolio (see Panel $\mathrm{C}$ of Table 11). Hence, rental income per dollar invested in the growth portfolio fell from 0.0400 initially to 0.0394 at the end of Year 5. In the same way, rental income per dollar invested in the value portfolio fell from 0.1005 to 0.0853 , still leaving a large gap in rental returns between the two portfolios in Year 5. 
A similar conclusion emerges from an analysis of capital growth (Table 11). Over the 5 years before portfolio formation, the average growth rate of capital value for the glamour portfolio was $0.08 \%$ per quarter versus $-3.27 \%$ for the value portfolio. Once again, investors can examine the post-formulation growth rates to see whether higher postformulation growth for glamour could justify its lower initial yield. Over the 5 postformulation years, capital growth averaged $-1.88 \%$ per quarter for glamour versus -0.42 $\%$ per quarter for value. Hence, the average capital growth rate of glamour properties was minus $2450 \%$ while that for value properties improved $87.16 \%$.

These findings are consistent with the extrapolation model. Glamour properties have historically grown faster in rental income and capital value relative to value properties. According to the initial yield, the market expected the superior growth of glamour properties to continue for many years. However, over the 5 years after formation, growth rates of glamour properties and value properties were essentially negative. The evidence suggests that forecasts had been tied to past growth rates and were too optimistic for glamour properties relative to value properties. In other words, these results are consistent with the extrapolation model. Contrarian/glamour investors were pleasantly/unpleasantly surprised by the post formation portfolio results. This implies that naïve extrapolation of past performance is a credible explanation for the superiority of the contrarian strategy ${ }^{4}$.

\section{Conclusion}

The paper set out to investigate the comparative advantage(s) of value portfolio and growth portfolio investments. The results of the study show that value portfolios outperformed (in both absolute and risk-adjusted bases) growth portfolios over all the holding periods under consideration. The average value premium for the four different holding periods ranges from $8.52 \%$ (1-quarter holding period) to $463.34 \%$ (longer holding periods). Any one who invested in value portfolios over the entire ten-year period would have been $1843.36 \%$ wealthier than one who invested in growth portfolios over the same period. The difference between the performances of the value portfolio and the growth portfolio has been found to be statistically significant at the 0.01 level. Thus, the null hypothesis that there is no difference between the mean returns for the two portfolios is rejected. The relative superiority of the value portfolio investment is confirmed by 
stochastic dominance test, which indicates that the value strategy is the optimal choice for both risk averters and risk lovers.

Furthermore, the superior performances of value portfolios occurred in all the four "states of the world". Therefore, the superior performance is not a compensation for higher risk as measured by the coefficient of variation (CV). The CVs for value portfolios were lower than growth portfolios in all the four holding periods. These findings are consistent with the contrarian strategy in finance. This consistency cannot be attributed to data snooping as the studies in the finance literature are based on different data. The findings imply that high initial yield office portfolios in the sample outperformed low yield prime office portfolios during the period under investigation. If the results can be generalized in any way, one may safely conclude that property investors should seriously consider contrarian real estate investment if they want to improve the performance of their portfolios. More research is, however, needed on the topic to validate/invalidate these results to help property investors make sound investment decisions to improve their investment return. 


\section{Notes:}

${ }^{1}$ Boykin and Gray (1994) trace the historical development of GIM in real estate appraisal and relate GIM to the price/earnings ratio that is frequently used in stock valuation and serves as a benchmark in the value approach to investing.

2 Marcato (2004) uses the terms "value" and "growth" properties in his paper on creating style indexes in real estate markets.

3 The choice of cities (markets) used for the study is constrained by the datasets and therefore data availability. Other Asia Pacific cities are not included in the study simply because of want of data.

${ }^{4}$ Notwithstanding the consistency of the results with the finance literature, one should note the significant differences between the studies in finance (based on stocks) and this study which is based on real property. Apart from the difference in liquidity of assets, studies in the finance literature are based on prices while this study is based on valuation estimates (capital values) and market rentals. Furthermore, while the studies in finance are based on prices of individual stocks, this study is based on sub-market averages. Although one may argue about the validity of results based on averages, the fact that the results are consistent with the finance literature may imply that it may not be prudent for one to tersely underestimate the validity of the results. After all, all studies that are based on market indices are based on average market figures; yet their validity is scarcely questioned. More research is, however, needed before any firm conclusion can be made. 


\section{References}

Arshanapali, B., Coggin, D. and Doukas, J. (1998) Multifactor Asset Pricing Analysis of International Value Investment, Journal of Portfolio Management, 24(4), 10-23.

Al-Khazali, O. (2002) Stochastic Dominance as a Decision Technique for Ranking Investments, Academy for Economics and Economic Education, 5(1), 1-8.

Amihud, Y., and Mendelson, H. (1986) Asset Pricing and the Bid-Ask Spread, Journal of Financial Economics, 17, 229-254.

Ball, R. and Kothari, S. (1989) Nonstationary Expected Returns, Journal of Financial Economics, 25(1), 51-74.

Banz, R. and Breen, W. (1986) Sample-Dependent Results Using Accounting and Market Data: Some Evidence, Journal of Finance, 41(4), 779-793.

Barrett, G.F. and Donald, S.G. (2003) Consistent Tests for Stochastic Dominance, Econometrica, 71(1), 71-104.

Bauman, S. and Miller, R.E. (1997) Investor Expectations and the Performance of Value Stocks versus Growth Stocks, Journal of Portfolio Management, 23(3), 57-68.

Bauman, W., and Conover, C. (1999) Investor Overreaction in International Stock Markets, Journal of Portfolio Management, 25(4), 102-110.

Bauman, W., Conover, C. and Miller, R. (2001) The Performance of Growth Stocks and Value Stocks in the Pacific Basin, Review of Pacific Basin Financial Markets and Policies, 4(2), 95-108.

Basu, S. (1977) Investment Performance of Common Stocks in Relation to their PriceEarnings Ratio: A Test of the Efficient Market Hypothesis, Journal of Finance, XXXII(3), 6763-6782.

Bhushan, R. (1989) Firm Characteristics and Analyst Following, Journal of Accounting and Economics, 11(2/3), 255-274.

Biswas, T. (1997) Decision Making Under Uncertainty, Macmillan Press Ltd., London.

Black, Fischer (1993) Beta and return, Journal of Portfolio Management 20, 8-18

Boykin, J.H. and Gray, M.T. (1994) The Relevance and Application of the Gross Income Multiplier, The Appraisal Journal, 62(2), 203-208.

Capaul, C., Rowley, I and Sharpe, W. (1993) International Value and Growth Stock Returns, Financial Analysts Journal, 49(1), 27-36.

Chan, K.C. (1988) On the Contrarian Investment Strategy, Journal of Business, 61(2), 147-164 
Chan, L., Hamao, Y. and Lakonishok, J. (1991) Fundamentals and Stock Returns in Japan, Journal of Finance, 46(5), 1739-1764.

Chan, L., Karceski, J. and Lakonishok, J. (2000) New Paradigm or Same Old Hype in Equity Investing? Financial Analysts Journal, 56(4), 23-36.

Chan, L., Karceski, J. and Lakonishok, J. (2003) The Level and Persistence of Growth Rates, Journal of Finance, 58(2), 643-684.

Chan, L., and Lakonishok, J. (2004) Value and Growth Investing: Review and Update, Financial Analysts Journal, 60(1), 71-86.

Chopra, N., Lakonishok, J. and Ritter, J. (1992) Measuring Abnormal Performance: Do stocks overreact? Journal of Financial Economics, 31(2), 235-268.

Daniel, K. and Titman, S. (1996) Evidence on the Characteristics of Cross Sectional Variation in Stock Returns, Working Paper (University of Chicago, Chicago, IL).

Davis, J. (1994) The Cross-Section of Realized Returns: The Pre-COMPUSTAT Evidence, Journal of Finance, 49(5), 1579-1593.

Davis, J. (1996) The Cross-Section of Stock Returns and Survivorship Bias: Evidence from Delisted Stocks, Quarterly Review of Economics and Finance, 36(3), 365-375.

De Bondt, W. and Thaler, R. (1985) Does the Stock Market Overreact? Journal of Finance, 40(3), 793-805.

Dechow, P., and Sloan, R. (1997) Returns to Contrarian Investment Strategies: Tests of Naïve Expectations Hypothesis, Journal of Financial Economics, 43(1), 3-27.

De Long, B., Shleifer, A, Summers, L. and Waldmann, R (1990) Noise Trader Risk in Financial Markets, Journal of Political Economy, 98(4), 703-738.

Dreman, David (1982) The New Contrarian Investment Strategy, Random House, New York.

Dreman D. and Berry, M. (1995) Overreaction, Underreaction and the Low-P/E Effect, Financial Analysts Journal, 51(4), 21-30.

Fama, E.F. and French, K.R. (1992) The Cross-Section of Expected Stock Returns, Journal of Foinance, 47, 427-65.

Fama E.F. and French, K.R. (1993) Common Risk Factors in the Returns on Stocks and Bonds, Journal of Financial Economics, 33(1) 3-56.

Fama E.F. and French, K.R. (1995) Size and Book-to-Market Factors in Earnings and Returns, Journal of Finance, 50(1), 131-155.

Fama E.F. and French, K.R. (1996) Multifactor Explanations of Asset Pricing Anomalies, Journal of Finance, 51(1) 55-84. 
Fama E.F. and French, K.R. (1998) Value versus Growth: The International Evidence, Journal of Finance, 53(6), 1975-1999.

Foster, F. Douglas, Smith, T. and Whaley, R.E. (1997) Assessing goodness of fit of asset pricing models: The distribution of the maximal $\mathrm{R}^{2}$, Journal of Finance 52, 591-607.

Geltner, D. and Miller, N. (2001) Commercial Real Estate Analysis and Investments, Prentice Hall, New Jersey.

Graham, B. and Dodd, D.L. (1934) Security Analysis, McGraw-Hill Book Company, Inc., New York.

Grundy, B.D. and Martin, J.S. (2001), Understanding the Nature of the Risks and the Sources of the Rewards of Momentum Investing, Review of Financial Studies, 14, 29-78.

Hadar, J. and Russel, W.R. (1969) Rules for Ordering Uncertain Prospects, American Economic Review, 59, 25-34.

Hanoch, G. and Levy, H. (1969) The Efficiency Analysis of Choices Involving Risk, The Review of Economic Studies, 36:3, 335-346.

Haugen, R.A. (1995), The New Finance: The Case Against Efficient Markets, Prentice Hall, New Jersey.

Jaffe, J., Keim, D.B. and Westerfield, R. (1989) Earning Yields, Market Values, and Stock Returns, Journal of Finance, 44, 135-148.

Jegadeesh, N., Kim, J., Krische, S. and Lee, C. (2004) Analyzing the Analysts: When Do Recommendations Add Value? Journal of Finance, 59(3), 1083-1124.

Jegadeesh, N. and Titman, S. (1993) Returns to Buying Winners and Selling Losers: Implications for Stock Market Efficiency, Journal of Finance, 48, 65-91.

Kjetsaa, R. and Kieff, M. (2003) Stochastic Dominance Analysis of Mutual Fund Performance, American Business Review, 21(1), 1-8.

Kothari, S.P., Shanken, J. and Sloan, R.G. (1995) Another Look at the Cross-Section of Expected Stock Returns, Journal of Finance, 50, 185-224.

La Porta, R. (1996) Expectations and the Cross-Section of Stock Returns, Journal of Finance, 51(5), 1715-1742.

La Porta, R., Lakonishok, J., Shleifer, A. and Vishny, R. (1997) Good news for Value Stocks: Further Evidence on Market Efficiency, Journal of Finance, 52(2), 859-874.

Lakonishok J., Shleifer, A. and Vishny, R. (1994) Contrarian Investment, Extrapolation and Risk, Journal of Finance, 49(5), 1541-1578. 
Levis, M. and Liodakis, M. (2001) Contrarian Strategies and Investor Expectations, Financial Analysts Journal, 57(2), 43-56.

Levy, H. (1992) Stochastic Dominance and Expected Utility: Survey and Analysis. Management Science, 38(4), 555-593.

Levy, H. and Sarnat, M. (1972) Investment and Portfolio Analysis, Wiley and Sons, New York.

Lo, A.W., and MacKinlay, A.C. (1990) Data-Snooping Biases in Tests of Financial Asset Pricing Models, Review of Financial Studies, 3, 431-468.

MacKinlay, A. Craig, (1995) Multifactor models do not explain deviations from the CAPM, Journal of Financial Economics 38, 3-28.

Marcato, G. (2004) Style Analysis in Real Estate Markets and the Construction of Value and Growth Indexes, Journal of Real Estate Portfolio Management, 10(3), 203-215.

Rosenberg, B., Reid, K. and Lanstein, R. (1985) Persuasive Evidence of Market Inefficiency, Journal of Portfolio Management, 11, 9-17.

Rothschild, D. and Stiglitz, J.E. (1970) Increasing Risk I: A Definition, Journal of Economic Theory, 2, 225-243.

Rouwenhorst, G.K. (1998) International Momentum Strategies, Journal of Finance, 53(1), 267-284.

Rouwenhorst, G.K. (1999) Local Returns Factors and Turnover in Emerging Stock Markets, Journal of Finance, 54(1), 267-284.

Sharpe, W., Alexander, G. and Bailey, J. (1998) Investments (6 ed.,) Prentice Hall, NJ.

Shleifer, A. and Vishny, R. (1990) The New Theory of the Firm: Equilibrium Short Horizons of Investors and Firms, AEA Papers and Proceedings, 80(2), 148-153.

Shleifer, A. and Vishny, R. (1997) The Limits of Arbitrage, Journal of Finance, 52(1), $35-55$.

Taylor, W. and Yoder, J. (1999) Load and No-Load Mutual Fund Dynamics During the 1987 Market Crash, Journal of Economics and Finance, 23, 155-165.

Tse, R.Y.C. (2002) Price-Earnings Ratios, Dividend Yields and Real Estate Stock Prices, Journal of Real Estate Portfolio Management, 8(2), 106-113.

Whitmore, G. A. (1970) Third Degree Stochastic Dominance, American Economic Review, 60, 457-459.

Williamson, J. (1970) Investments - New Analytic Techniques, Praeger, New York. 
Table 1a: Composition of Decile Portfolios (1994 Q2 to 1999 Q2)

\begin{tabular}{|c|c|c|c|c|c|c|c|c|c|c|c|c|c|c|c|c|c|c|c|c|}
\hline & $\begin{array}{l}\mathscr{0} \\
\stackrel{0}{0} \\
\text { ’́ } \\
\stackrel{\omega}{\omega}\end{array}$ & 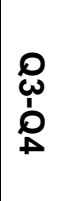 & 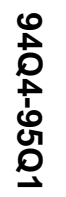 & Dِ & 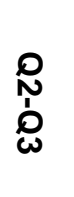 & 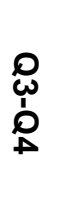 & 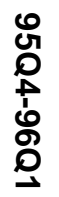 & D & $\begin{array}{l}\text { ్ْస్ } \\
\text { D્డ }\end{array}$ & 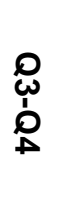 & $\begin{array}{l}\mathscr{8} \\
\stackrel{D}{0} \\
+ \\
0 \\
0 \\
0\end{array}$ & 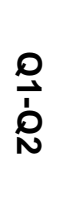 & $\begin{array}{l}\text { న్ } \\
\text { ஹ્డ }\end{array}$ & 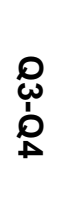 & $\begin{array}{l}\mathscr{1} \\
0 \\
0 \\
\dot{1} \\
0 \\
0 \\
0\end{array}$ & $\stackrel{\rho}{\stackrel{\rho}{0}}$ & $\begin{array}{l}\text { న } \\
\text { ఏ్ట }\end{array}$ & 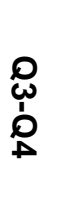 & $\begin{array}{l}0 \\
0 \\
0 \\
\vdots \\
0 \\
\varnothing \\
\varrho\end{array}$ & ڤِ \\
\hline Auckland CBD & 4 & 4 & 4 & 4 & 4 & 4 & 4 & 4 & 4 & 4 & 4 & 3 & 3 & 3 & 4 & 4 & 3 & 4 & 3 & 4 \\
\hline Auckland Non-CBD & 4 & 4 & 4 & 4 & 3 & 3 & 3 & 3 & 3 & 3 & 3 & 3 & 3 & 3 & 3 & 3 & 3 & 3 & 3 & 3 \\
\hline Bangkok CBD & 1 & 1 & 1 & 1 & 1 & 1 & 1 & 1 & 1 & 1 & 1 & 1 & 2 & 2 & 2 & 2 & 1 & 1 & 1 & 1 \\
\hline Beijing CBD & & & & & & & & & & & & & & & & & 1 & 2 & 2 & 2 \\
\hline HK Central & 3 & 3 & 3 & 2 & 3 & 3 & 3 & 3 & 3 & 3 & 3 & 3 & 3 & 3 & 3 & 3 & 3 & 3 & 3 & 3 \\
\hline HK Wanchai & 3 & 3 & 3 & 3 & 3 & 3 & 3 & 3 & 3 & 4 & 4 & 4 & 4 & 4 & 3 & 3 & 4 & 4 & 4 & 4 \\
\hline HK Tsimshatsui & 3 & 3 & 3 & 3 & 4 & 4 & 4 & 4 & 4 & 3 & 3 & 4 & 4 & 3 & 3 & 3 & 3 & 3 & 3 & 3 \\
\hline \multicolumn{21}{|l|}{ HK East } \\
\hline Jakarta CBD & 2 & 2 & 2 & 3 & 2 & 2 & 2 & 2 & 2 & 2 & 2 & 2 & 2 & 1 & 1 & 1 & 2 & 2 & 1 & 1 \\
\hline KLCity Centre & 2 & 2 & 2 & 2 & 2 & 2 & 2 & 2 & 2 & 2 & 2 & 2 & 1 & 2 & 2 & 2 & 2 & 2 & 2 & 1 \\
\hline KL Decentralised & 2 & 2 & 2 & 2 & 2 & 2 & 2 & 2 & 2 & 2 & 2 & 2 & 2 & 2 & 2 & 2 & 2 & 2 & 2 & 2 \\
\hline Makati CBD & 1 & 1 & 1 & 1 & 1 & 1 & 1 & 1 & 1 & 1 & 1 & 1 & 1 & 1 & 1 & 1 & 1 & 1 & 1 & 1 \\
\hline \multicolumn{21}{|l|}{ Seoul CBD } \\
\hline \multicolumn{21}{|l|}{ Seoul Yoido CBD } \\
\hline \multicolumn{21}{|l|}{ Seoul Gangnam CBD } \\
\hline Shanghai Puxi & 1 & 1 & 1 & 1 & 1 & 1 & 1 & 1 & 1 & 1 & 1 & 1 & 1 & 1 & 1 & 1 & 1 & 1 & 1 & 2 \\
\hline Shanghai Pudong & & & & & & & & & 1 & 1 & 1 & 1 & 1 & 1 & 1 & 1 & 2 & 1 & 2 & 2 \\
\hline Raffles Place ${ }^{\star}$ & 4 & 4 & 4 & 4 & 4 & 4 & 4 & 4 & 4 & 4 & 4 & 4 & 4 & 4 & 4 & 4 & 4 & 4 & 4 & 4 \\
\hline Shenton Way* & & & & & & & & & 4 & 4 & 4 & 4 & 4 & 4 & 4 & 4 & 4 & 4 & 4 & 4 \\
\hline \multicolumn{21}{|l|}{ Marina Bay ${ }^{\star}$} \\
\hline Tokyo CBD & & & & & & & & & & & & & 3 & 4 & 4 & 4 & 4 & 3 & 4 & 3 \\
\hline
\end{tabular}


Table 1b: Composition of Decile Portfolios (1999 Q2 to 2004 Q2)

\begin{tabular}{|c|c|c|c|c|c|c|c|c|c|c|c|c|c|c|c|c|c|c|c|c|}
\hline & 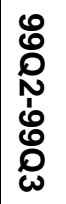 & 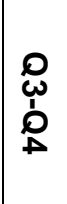 & $\begin{array}{l}0 \\
8 \\
0 \\
+ \\
0 \\
0 \\
0\end{array}$ & Dِ & 怘 & 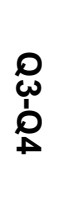 & $\begin{array}{l}8 \\
0 \\
0 \\
1 \\
0 \\
0 \\
0 \\
\end{array}$ & 号 & $\begin{array}{l}\text { న } \\
\text { อి }\end{array}$ & 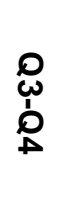 & $\begin{array}{l}0 \\
0 \\
0 \\
0 \\
0 \\
0 \\
0\end{array}$ & هِ & 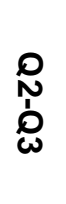 & $\begin{array}{l}0 \\
\mathscr{W} \\
0 \\
\not \subset\end{array}$ & 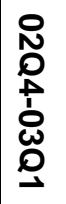 & هِ & 怘 & 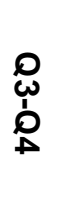 & 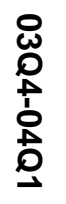 & Dُ \\
\hline Auckland CBD & 4 & 4 & 4 & 4 & 4 & 4 & 4 & 4 & 4 & 4 & 4 & 4 & 4 & 4 & 4 & 4 & 4 & 4 & 4 & 4 \\
\hline Auckland Non-CBD & 3 & 3 & 3 & 3 & 4 & 4 & 4 & 4 & 4 & 4 & 4 & 4 & 4 & 4 & 4 & 4 & 4 & 4 & 4 & 4 \\
\hline Bangkok CBD & 1 & 2 & 2 & 2 & 1 & 1 & 2 & 2 & 2 & 2 & 2 & 1 & 1 & 1 & 2 & 1 & 1 & 1 & 1 & 1 \\
\hline Beijing CBD & 2 & 2 & 2 & 2 & 2 & 2 & 1 & 1 & 1 & 1 & 1 & 1 & 1 & 2 & 2 & 1 & 2 & 2 & 2 & 2 \\
\hline HK Central & 3 & 3 & 3 & 3 & 3 & 3 & 2 & 2 & 3 & 3 & 3 & 3 & 3 & 4 & 3 & 4 & 4 & 4 & 3 & 3 \\
\hline HK Wanchai & 3 & 4 & 4 & 4 & 4 & 3 & 3 & 3 & 3 & 4 & 4 & 4 & 4 & 4 & 4 & 4 & 4 & 4 & 4 & 4 \\
\hline HK Tsimshatsui & 2 & 3 & 3 & 3 & 2 & 2 & 3 & 3 & 3 & 3 & 3 & 3 & 3 & 3 & 3 & 3 & 3 & 3 & 3 & 3 \\
\hline HK East & 3 & 2 & 2 & 2 & 2 & 2 & 2 & 2 & 2 & 2 & 3 & 3 & 3 & 3 & 3 & 3 & 3 & 3 & 3 & 3 \\
\hline Jakarta CBD & 1 & 1 & 1 & 1 & 1 & 1 & 1 & 1 & 1 & 1 & 1 & 1 & 1 & 1 & 1 & 1 & 2 & 1 & 1 & 1 \\
\hline KLCity Centre & 1 & 2 & 2 & 2 & 2 & 2 & 2 & 2 & 2 & 2 & 2 & 2 & 2 & 2 & 2 & 2 & 2 & 2 & 2 & 2 \\
\hline KL Decentralised & 3 & 3 & 2 & 2 & 3 & 3 & 3 & 3 & 3 & 3 & 3 & 3 & 3 & 3 & 3 & 3 & 3 & 3 & 3 & 3 \\
\hline Makati CBD & 1 & 1 & 1 & 1 & 2 & 2 & 2 & 2 & 2 & 2 & 2 & 2 & 2 & 2 & 2 & 2 & 2 & 2 & 2 & 2 \\
\hline Seoul CBD & & 1 & 1 & 1 & 1 & 1 & 1 & 1 & 1 & 1 & 1 & 1 & 2 & 1 & 1 & 2 & 1 & 2 & 2 & 2 \\
\hline Seoul Yoido CBD & & 1 & 1 & 1 & 1 & 1 & 1 & 1 & 1 & 1 & 1 & 2 & 1 & 1 & 1 & 2 & 1 & 1 & 1 & 1 \\
\hline Seoul Gangnam CBD & & 1 & 1 & 1 & 1 & 1 & 1 & 1 & 1 & 1 & 1 & 1 & 1 & 1 & 1 & 1 & 1 & 1 & 1 & 1 \\
\hline Shanghai Puxi & 2 & 2 & 3 & 3 & 3 & 3 & 3 & 3 & 2 & 2 & 2 & 2 & 2 & 2 & 2 & 2 & 2 & 2 & 2 & 2 \\
\hline Shanghai Pudong & 2 & 3 & 3 & 3 & 3 & 3 & 3 & 3 & 3 & 3 & 2 & 2 & 2 & 2 & 1 & 1 & 1 & 1 & 1 & 1 \\
\hline Raffles Place ${ }^{\star}$ & 4 & 4 & 4 & 4 & 3 & 4 & 4 & 4 & 4 & 4 & 4 & 3 & 3 & 3 & 3 & 3 & 3 & 3 & 4 & 3 \\
\hline Shenton Way* & 4 & 4 & 4 & 4 & 4 & 4 & 4 & 4 & 4 & 3 & 3 & 3 & 3 & 3 & 3 & 3 & 3 & 3 & 3 & 4 \\
\hline Marina Bay* & & & & & & 3 & 3 & 3 & 3 & 3 & 3 & 4 & 4 & 3 & 4 & 3 & 3 & 3 & 4 & 4 \\
\hline Tokyo CBD & 4 & 4 & 4 & 4 & 4 & 4 & 4 & 4 & 4 & 4 & 4 & 4 & 4 & 4 & 4 & 4 & 4 & 4 & 3 & 3 \\
\hline
\end{tabular}

* Singapore 
Table 2: Median Rental-to-Price Ratio

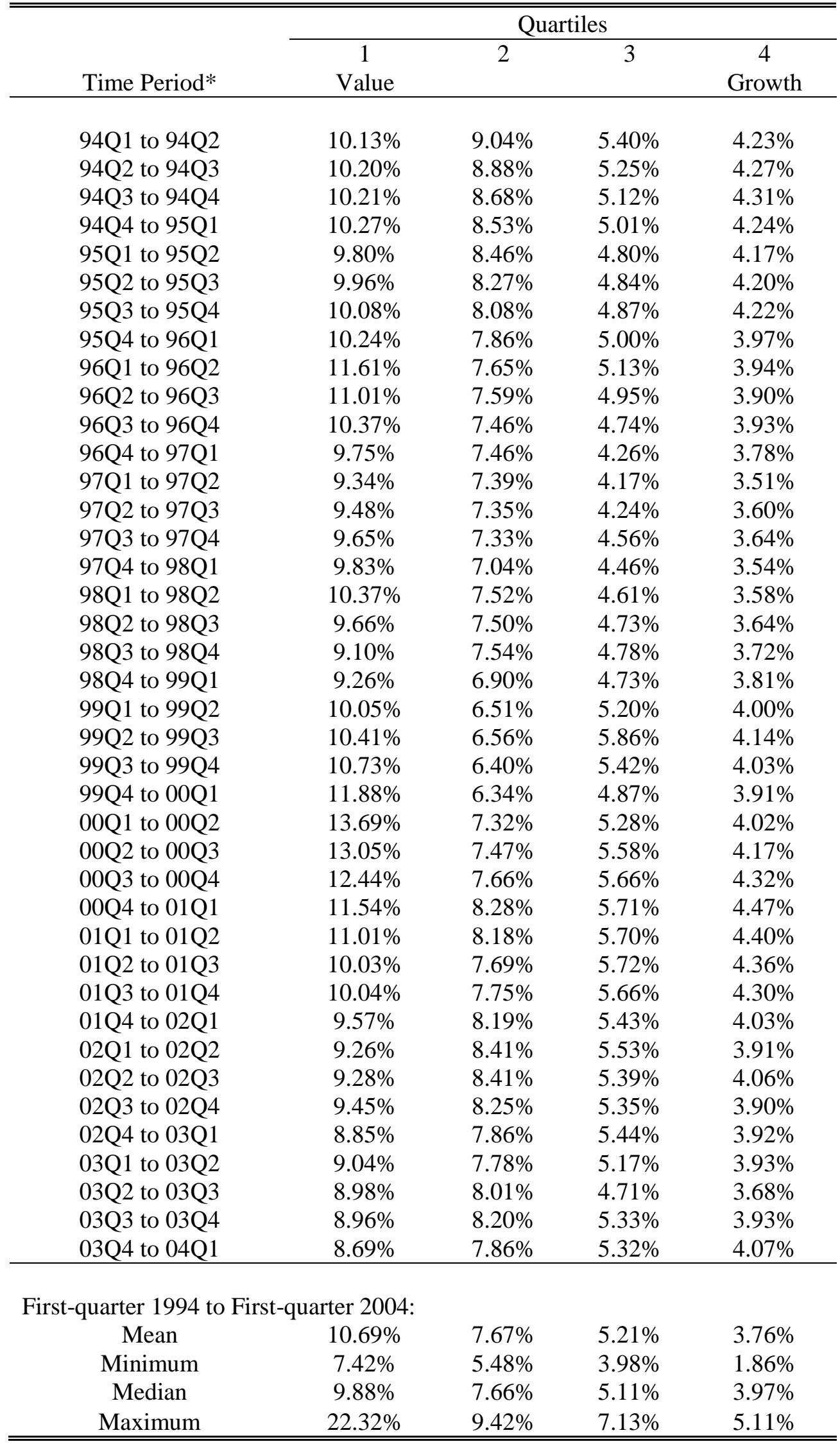

* The overlapping periods accommodate investors who enter the market at different periods. 
Table 3: Returns for Quartile Portfolios (1-quarter Holding-Period)

\begin{tabular}{|c|c|c|c|c|c|}
\hline \multirow[b]{2}{*}{ Time Period } & \multicolumn{4}{|c|}{ Initial Yield Quartiles } & \multirow[b]{2}{*}{$\begin{array}{l}\text { Spread between } \\
\quad 1 \& 4\end{array}$} \\
\hline & $\begin{array}{c}1 \\
\text { Value }\end{array}$ & 2 & 3 & $\begin{array}{c}4 \\
\text { Growth }\end{array}$ & \\
\hline 94Q2 - 94Q3 & $17.98 \%$ & $9.55 \%$ & $10.52 \%$ & $9.37 \%$ & $8.62 \%$ \\
\hline 94Q3 - 94Q4 & $17.64 \%$ & $9.29 \%$ & $10.26 \%$ & $9.02 \%$ & $8.62 \%$ \\
\hline 94Q4 - 95Q1 & $17.41 \%$ & $9.15 \%$ & $10.02 \%$ & $7.94 \%$ & $9.47 \%$ \\
\hline 95Q1 - 95Q2 & $13.10 \%$ & $7.03 \%$ & $0.49 \%$ & $5.80 \%$ & $7.30 \%$ \\
\hline 95Q2 - 95Q3 & $12.80 \%$ & $8.51 \%$ & $1.32 \%$ & $3.87 \%$ & $8.93 \%$ \\
\hline 95Q3 - 95Q4 & $12.52 \%$ & $8.46 \%$ & $1.51 \%$ & $4.03 \%$ & $8.49 \%$ \\
\hline 95Q4 - 96Q1 & $12.19 \%$ & $8.39 \%$ & $0.89 \%$ & $3.50 \%$ & $8.70 \%$ \\
\hline 96Q1 - 96Q2 & $11.81 \%$ & $6.80 \%$ & $14.09 \%$ & $7.55 \%$ & $4.26 \%$ \\
\hline 96Q2 - 96Q3 & $11.31 \%$ & $6.73 \%$ & $12.79 \%$ & $7.37 \%$ & $3.95 \%$ \\
\hline 96Q3 - 96Q4 & $10.77 \%$ & $6.58 \%$ & $10.62 \%$ & $8.01 \%$ & $2.75 \%$ \\
\hline 96Q4 - 97Q1 & $10.25 \%$ & $6.46 \%$ & $9.95 \%$ & $7.86 \%$ & $2.39 \%$ \\
\hline 97Q1 - 97Q2 & $3.11 \%$ & $2.36 \%$ & $3.50 \%$ & $-0.39 \%$ & $3.50 \%$ \\
\hline 97Q2 - 97Q3 & $5.50 \%$ & $-2.66 \%$ & $2.66 \%$ & $-0.49 \%$ & $5.99 \%$ \\
\hline 97Q3 - 97Q4 & $5.93 \%$ & $-5.73 \%$ & $2.48 \%$ & $-0.62 \%$ & $6.55 \%$ \\
\hline 97Q4 - 98Q1 & $5.46 \%$ & $-8.69 \%$ & $0.83 \%$ & $0.63 \%$ & $4.83 \%$ \\
\hline 98Q1 - 98Q2 & $3.32 \%$ & $5.16 \%$ & $-5.00 \%$ & $-1.30 \%$ & $4.62 \%$ \\
\hline 98Q2 - 98Q3 & $5.14 \%$ & $-0.39 \%$ & $-2.75 \%$ & $-6.17 \%$ & $11.30 \%$ \\
\hline 98Q3 - 98Q4 & $7.11 \%$ & $-1.37 \%$ & $-4.00 \%$ & $-8.15 \%$ & $15.26 \%$ \\
\hline 98Q4 - 99Q1 & $0.46 \%$ & $2.17 \%$ & $-5.86 \%$ & $-9.65 \%$ & $10.12 \%$ \\
\hline 99Q1 - 99Q2 & $9.49 \%$ & $4.22 \%$ & $6.31 \%$ & $4.25 \%$ & $5.23 \%$ \\
\hline 99Q2 - 99Q3 & $9.18 \%$ & $1.99 \%$ & $6.54 \%$ & $3.63 \%$ & $5.55 \%$ \\
\hline 99Q3 - 99Q4 & $5.57 \%$ & $5.37 \%$ & $4.65 \%$ & $4.30 \%$ & $1.27 \%$ \\
\hline 99Q4 - 00Q1 & $11.58 \%$ & $6.12 \%$ & $3.85 \%$ & $4.09 \%$ & $7.50 \%$ \\
\hline 00Q1 - 00Q2 & $14.39 \%$ & $10.61 \%$ & $5.33 \%$ & $2.88 \%$ & $11.51 \%$ \\
\hline 00Q2 - 00Q3 & $19.66 \%$ & $8.86 \%$ & $5.73 \%$ & $2.73 \%$ & $16.93 \%$ \\
\hline 00Q3 - 00Q4 & $14.78 \%$ & $8.14 \%$ & $6.90 \%$ & $3.18 \%$ & $11.60 \%$ \\
\hline 00Q4 - 01Q1 & $14.65 \%$ & $6.12 \%$ & $7.29 \%$ & $3.32 \%$ & $11.32 \%$ \\
\hline 01Q1 - 01Q2 & $11.83 \%$ & $6.18 \%$ & $3.77 \%$ & $-0.30 \%$ & $12.13 \%$ \\
\hline 01Q2 - 01Q3 & $12.15 \%$ & $5.09 \%$ & $4.74 \%$ & $-0.16 \%$ & $12.31 \%$ \\
\hline 01Q3 - 01Q4 & $18.03 \%$ & $7.59 \%$ & $2.06 \%$ & $0.46 \%$ & $17.58 \%$ \\
\hline 01Q4 - 02Q1 & $7.25 \%$ & $7.98 \%$ & $0.24 \%$ & $0.21 \%$ & $7.03 \%$ \\
\hline 02Q1 - 02Q2 & $10.10 \%$ & $8.28 \%$ & $3.80 \%$ & $0.85 \%$ & $9.25 \%$ \\
\hline 02Q2 - 02Q3 & $13.51 \%$ & $8.43 \%$ & $2.72 \%$ & $2.18 \%$ & $11.33 \%$ \\
\hline 02Q3 - 02Q4 & $17.22 \%$ & $7.57 \%$ & $0.85 \%$ & $-0.21 \%$ & $17.43 \%$ \\
\hline 02Q4 - 03Q1 & $5.98 \%$ & $8.31 \%$ & $2.71 \%$ & $1.35 \%$ & $4.63 \%$ \\
\hline 03Q1 - 03Q2 & $11.05 \%$ & $8.35 \%$ & $3.65 \%$ & $0.14 \%$ & $10.91 \%$ \\
\hline 03Q2 - 03Q3 & $11.02 \%$ & $7.23 \%$ & $0.03 \%$ & $-4.31 \%$ & $15.33 \%$ \\
\hline 03Q3 - 03Q4 & $14.63 \%$ & $9.15 \%$ & $4.36 \%$ & $4.46 \%$ & $10.17 \%$ \\
\hline 03Q4 - 04Q1 & $7.76 \%$ & $6.67 \%$ & $9.01 \%$ & $6.95 \%$ & $0.81 \%$ \\
\hline 04Q1 - 04Q2 & $13.90 \%$ & $10.16 \%$ & $21.92 \%$ & $8.40 \%$ & $5.50 \%$ \\
\hline \multicolumn{6}{|c|}{$\begin{array}{l}\text { Quarter Performance for Portfolios in the Period 94Q2 to 04Q2: } \\
\text { Arithmetic }\end{array}$} \\
\hline $\begin{array}{l}\text { Mean Return } \\
\text { Mean }\end{array}$ & $10.94 \%$ & $5.76 \%$ & $4.52 \%$ & $2.41 \%$ & $8.52 \%$ \\
\hline Volatility & $4.62 \%$ & $4.29 \%$ & $5.39 \%$ & $4.48 \%$ & $4.36 \%$ \\
\hline
\end{tabular}


Table 4: Returns for Quartile Portfolios (3-year Holding-Period)

\begin{tabular}{|c|c|c|c|c|c|}
\hline \multirow[b]{2}{*}{ Time Period } & \multicolumn{4}{|c|}{ Initial Yield Quartiles } & \multirow[b]{2}{*}{$\begin{array}{c}\text { Spread between } 1 \\
\& 4\end{array}$} \\
\hline & $\begin{array}{c}1 \\
\text { Value }\end{array}$ & 2 & 3 & $\begin{array}{c}4 \\
\text { Growth }\end{array}$ & \\
\hline 94Q2 - 97Q2 & $309.06 \%$ & $139.56 \%$ & $104.67 \%$ & $121.85 \%$ & $187.21 \%$ \\
\hline 94Q3 - 97Q3 & $246.04 \%$ & $123.22 \%$ & $83.78 \%$ & $110.43 \%$ & $135.61 \%$ \\
\hline 94Q4 - 97Q4 & $187.34 \%$ & $107.60 \%$ & $65.47 \%$ & $99.69 \%$ & $87.65 \%$ \\
\hline 95Q1 - 98Q1 & $131.40 \%$ & $80.49 \%$ & $60.75 \%$ & $90.70 \%$ & $40.70 \%$ \\
\hline 95Q2 - 98Q2 & $122.39 \%$ & $74.88 \%$ & $66.41 \%$ & $53.18 \%$ & $69.21 \%$ \\
\hline 95Q3 - 98Q3 & $113.34 \%$ & $57.18 \%$ & $55.31 \%$ & $40.17 \%$ & $73.17 \%$ \\
\hline 95Q4 - 98Q4 & $104.36 \%$ & $39.13 \%$ & $41.54 \%$ & $25.68 \%$ & $78.69 \%$ \\
\hline 96Q1 - 99Q1 & $95.31 \%$ & $20.26 \%$ & $26.87 \%$ & $11.14 \%$ & $84.17 \%$ \\
\hline 96Q2 - 99Q2 & $97.72 \%$ & $23.25 \%$ & $19.18 \%$ & $-0.27 \%$ & $97.99 \%$ \\
\hline 96Q3 - 99Q3 & $87.25 \%$ & $26.12 \%$ & $12.95 \%$ & $-4.40 \%$ & $91.65 \%$ \\
\hline 96Q4 - 99Q4 & $77.44 \%$ & $28.79 \%$ & $7.31 \%$ & $-8.36 \%$ & $85.80 \%$ \\
\hline 97Q1 - 00Q1 & $68.16 \%$ & $31.38 \%$ & $28.21 \%$ & $-26.78 \%$ & $94.94 \%$ \\
\hline 97Q2 - 00Q2 & $81.27 \%$ & $29.33 \%$ & $35.49 \%$ & $-22.67 \%$ & $103.94 \%$ \\
\hline 97Q3 - 00Q3 & $69.47 \%$ & $55.28 \%$ & $17.74 \%$ & $-2.71 \%$ & $72.19 \%$ \\
\hline 97Q4 - 00Q4 & $67.74 \%$ & $72.51 \%$ & $8.93 \%$ & $12.25 \%$ & $55.49 \%$ \\
\hline 98Q1 - 01Q1 & $66.46 \%$ & $100.90 \%$ & $13.90 \%$ & $15.33 \%$ & $51.13 \%$ \\
\hline 98Q2 - 01Q2 & $103.27 \%$ & $77.53 \%$ & $27.73 \%$ & $12.84 \%$ & $90.43 \%$ \\
\hline 98Q3 - 01Q3 & $84.74 \%$ & $111.82 \%$ & $47.20 \%$ & $9.87 \%$ & $74.87 \%$ \\
\hline 98Q4 - 01Q4 & $104.47 \%$ & $114.89 \%$ & $44.91 \%$ & $28.07 \%$ & $76.40 \%$ \\
\hline 99Q1 - 02Q1 & $134.21 \%$ & $112.75 \%$ & $68.01 \%$ & $30.31 \%$ & $103.89 \%$ \\
\hline 99Q2 - 02Q2 & $133.09 \%$ & $119.53 \%$ & $78.70 \%$ & $21.75 \%$ & $111.34 \%$ \\
\hline 99Q3 - 02Q3 & $280.07 \%$ & $145.96 \%$ & $78.46 \%$ & $26.09 \%$ & $253.97 \%$ \\
\hline 99Q4 - 02Q4 & $319.09 \%$ & $142.27 \%$ & $80.25 \%$ & $20.71 \%$ & $298.38 \%$ \\
\hline 00Q1 - 03Q1 & $295.97 \%$ & $143.36 \%$ & $81.64 \%$ & $17.55 \%$ & $278.42 \%$ \\
\hline 00Q2 - 03Q2 & $319.80 \%$ & $109.76 \%$ & $83.91 \%$ & $16.04 \%$ & $303.76 \%$ \\
\hline 00Q3 - 03Q3 & $292.67 \%$ & $97.43 \%$ & $63.90 \%$ & $14.40 \%$ & $278.27 \%$ \\
\hline 00Q4 - 03Q4 & $287.24 \%$ & $88.91 \%$ & $69.30 \%$ & $15.80 \%$ & $271.44 \%$ \\
\hline 01Q1 - 04Q1 & $254.47 \%$ & $98.17 \%$ & $71.67 \%$ & $18.10 \%$ & $236.37 \%$ \\
\hline 01Q2 - 04Q2 & $258.10 \%$ & $141.31 \%$ & $81.79 \%$ & $24.41 \%$ & $233.68 \%$ \\
\hline 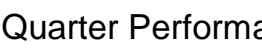 & $\Omega_{0}$ & e Perioc & $004 C$ & & \\
\hline Arithmetic Me & $n$ & $86.67 \%$ & $52.62 \%$ & $26.59 \%$ & $138.65 \%$ \\
\hline Mean Volati & & $41.37 \%$ & $27.81 \%$ & $36.42 \%$ & $87.12 \%$ \\
\hline
\end{tabular}


Table 5: Returns for Quartile Portfolios (5-year Holding-Period)

\begin{tabular}{|c|c|c|c|c|c|}
\hline \multirow[b]{2}{*}{ Time Period } & \multicolumn{4}{|c|}{ Initial Yield Quartiles } & \multirow[b]{2}{*}{$\begin{array}{c}\text { Spread } \\
\text { between } 1 \text { \& } 4\end{array}$} \\
\hline & $\begin{array}{c}1 \\
\text { Value }\end{array}$ & 2 & 3 & $\begin{array}{c}4 \\
\text { Growth }\end{array}$ & \\
\hline 94Q2 - 99Q2 & $445.21 \%$ & $138.18 \%$ & $30.80 \%$ & $145.28 \%$ & $299.93 \%$ \\
\hline 94Q3 - 99Q3 & $389.81 \%$ & $137.46 \%$ & $26.75 \%$ & $130.82 \%$ & $258.99 \%$ \\
\hline 94Q4 - 99Q4 & $339.59 \%$ & $136.48 \%$ & $22.62 \%$ & $117.04 \%$ & $222.55 \%$ \\
\hline 95Q1 - 00Q1 & $293.56 \%$ & $115.15 \%$ & $29.92 \%$ & $105.61 \%$ & $187.95 \%$ \\
\hline 95Q2 - 00Q2 & $268.45 \%$ & $133.13 \%$ & $76.77 \%$ & $46.52 \%$ & $221.93 \%$ \\
\hline 95Q3 - 00Q3 & $242.26 \%$ & $131.17 \%$ & $82.91 \%$ & $50.09 \%$ & $192.18 \%$ \\
\hline 95Q4 - 00Q4 & $209.90 \%$ & $129.00 \%$ & $89.69 \%$ & $50.53 \%$ & $159.37 \%$ \\
\hline 96Q1 - 01Q1 & $184.79 \%$ & $127.10 \%$ & $98.67 \%$ & $51.02 \%$ & $133.77 \%$ \\
\hline 96Q2 - 01Q2 & $186.64 \%$ & $127.66 \%$ & $78.65 \%$ & $30.18 \%$ & $156.46 \%$ \\
\hline 96Q3 - 01Q3 & $171.95 \%$ & $128.63 \%$ & $70.02 \%$ & $17.61 \%$ & $154.34 \%$ \\
\hline 96Q4 - 01Q4 & $167.95 \%$ & $129.89 \%$ & $57.44 \%$ & $7.92 \%$ & $160.03 \%$ \\
\hline 97Q1 - $02 Q 1$ & $163.70 \%$ & $130.33 \%$ & $61.92 \%$ & $-9.49 \%$ & $173.20 \%$ \\
\hline 97Q2 - 02Q2 & $193.52 \%$ & $127.19 \%$ & $63.20 \%$ & $-6.73 \%$ & $200.25 \%$ \\
\hline 97Q3 - 02Q3 & $191.43 \%$ & $167.40 \%$ & $47.56 \%$ & $6.36 \%$ & $185.07 \%$ \\
\hline 97Q4 - 02Q4 & $196.85 \%$ & $201.60 \%$ & $29.38 \%$ & $18.32 \%$ & $178.53 \%$ \\
\hline 98Q1 - 03Q1 & $205.17 \%$ & $258.15 \%$ & $29.32 \%$ & $20.38 \%$ & $184.79 \%$ \\
\hline 98Q2 - 03Q2 & $283.25 \%$ & $226.23 \%$ & $48.27 \%$ & $14.44 \%$ & $268.81 \%$ \\
\hline 98Q3 - 03Q3 & $255.19 \%$ & $291.14 \%$ & $56.88 \%$ & $13.35 \%$ & $241.84 \%$ \\
\hline 98Q4 - 03Q4 & $307.76 \%$ & $292.00 \%$ & $63.85 \%$ & $34.13 \%$ & $273.63 \%$ \\
\hline 99Q1 - 04Q1 & $373.71 \%$ & $287.46 \%$ & $97.79 \%$ & $52.72 \%$ & $320.98 \%$ \\
\hline 99Q2 - 04Q2 & $383.11 \%$ & $320.23 \%$ & $146.84 \%$ & $52.41 \%$ & $330.70 \%$ \\
\hline
\end{tabular}

Quarter Performance for Portfolios in the Period 94Q2 to 04Q2:

Arithmetic

$\begin{array}{lrrrrr}\text { Mean } & 259.71 \% & 177.88 \% & 62.35 \% & 45.17 \% & 214.54 \% \\ \begin{array}{l}\text { Return } \\ \text { Mean }\end{array} & & & & & \\ \text { Volatility } & 85.17 \% & 69.88 \% & 30.79 \% & 44.36 \% & 57.92 \%\end{array}$


Table 6: Returns for Quartile Portfolios (Entire Holding-Period)

\begin{tabular}{|c|c|c|c|c|c|}
\hline \multirow[b]{2}{*}{ Time Period } & \multicolumn{4}{|c|}{ Initial Yield Quartiles } & \multirow[b]{2}{*}{$\begin{array}{l}\text { Spread } \\
\text { between } 1 \& 4\end{array}$} \\
\hline & $\begin{array}{c}1 \\
\text { Value }\end{array}$ & 2 & 3 & $\begin{array}{c}4 \\
\text { Growth }\end{array}$ & \\
\hline 94Q2 - 04Q2 & $2117.48 \%$ & $956.51 \%$ & $258.35 \%$ & $274.12 \%$ & $1843.36 \%$ \\
\hline 94Q3 - 04Q2 & $1779.51 \%$ & $864.43 \%$ & $224.24 \%$ & $242.08 \%$ & $1537.43 \%$ \\
\hline 94Q4 - 04Q2 & $1497.66 \%$ & $782.46 \%$ & $194.08 \%$ & $213.78 \%$ & $1283.88 \%$ \\
\hline 95Q1 - 04Q2 & $1260.77 \%$ & $492.04 \%$ & $275.80 \%$ & $190.70 \%$ & $1070.08 \%$ \\
\hline 95Q2 - 04Q2 & $1103.14 \%$ & $644.82 \%$ & $199.32 \%$ & $159.70 \%$ & $943.44 \%$ \\
\hline 95Q3 - 04Q2 & $966.66 \%$ & $586.42 \%$ & $195.41 \%$ & $150.02 \%$ & $816.63 \%$ \\
\hline 95Q4 - 04Q2 & $847.97 \%$ & $532.88 \%$ & $191.02 \%$ & $140.35 \%$ & $707.62 \%$ \\
\hline 96Q1 - 04Q2 & $744.94 \%$ & $483.87 \%$ & $188.46 \%$ & $132.23 \%$ & $612.70 \%$ \\
\hline 96Q2 - 04Q2 & $707.78 \%$ & $446.70 \%$ & $152.84 \%$ & $85.31 \%$ & $622.46 \%$ \\
\hline 96Q3 - 04Q2 & $625.68 \%$ & $412.20 \%$ & $173.47 \%$ & $48.27 \%$ & $577.41 \%$ \\
\hline 96Q4 - 04Q2 & $555.15 \%$ & $380.60 \%$ & $147.21 \%$ & $37.27 \%$ & $517.88 \%$ \\
\hline 97Q1 - 04Q2 & $494.23 \%$ & $351.45 \%$ & $110.07 \%$ & $33.10 \%$ & $461.13 \%$ \\
\hline 97Q2 - 04Q2 & $434.44 \%$ & $389.05 \%$ & $106.75 \%$ & $33.63 \%$ & $400.82 \%$ \\
\hline 97Q3 - 04Q2 & $408.10 \%$ & $400.93 \%$ & $106.70 \%$ & $32.57 \%$ & $375.53 \%$ \\
\hline 97Q4 - 04Q2 & $379.64 \%$ & $431.40 \%$ & $87.50 \%$ & $42.00 \%$ & $337.64 \%$ \\
\hline 98Q1 - 04Q2 & $354.79 \%$ & $481.95 \%$ & $85.96 \%$ & $41.10 \%$ & $313.69 \%$ \\
\hline 98Q2 - 04Q2 & $466.08 \%$ & $344.71 \%$ & $99.66 \%$ & $41.69 \%$ & $424.39 \%$ \\
\hline 98Q3 - 04Q2 & $392.97 \%$ & $386.25 \%$ & $123.28 \%$ & $38.52 \%$ & $354.45 \%$ \\
\hline 98Q4 - 04Q2 & $402.30 \%$ & $353.40 \%$ & $115.04 \%$ & $63.47 \%$ & $338.83 \%$ \\
\hline 99Q1 - 04Q2 & $428.94 \%$ & $318.86 \%$ & $145.60 \%$ & $67.98 \%$ & $360.96 \%$ \\
\hline \multicolumn{6}{|c|}{$\begin{array}{l}\text { Quarter Performance for Portfolios in the Period } 94 \mathrm{Q} 2 \text { to } 04 \mathrm{Q} 2 \text { : } \\
\text { Arithmetic }\end{array}$} \\
\hline $\begin{array}{l}\text { Mean } \\
\text { Return }\end{array}$ & $798.41 \%$ & $502.05 \%$ & $159.04 \%$ & $103.39 \%$ & $695.02 \%$ \\
\hline $\begin{array}{l}\text { Mean } \\
\text { Volatility }\end{array}$ & $510.25 \%$ & $180.08 \%$ & $55.94 \%$ & $78.41 \%$ & $434.91 \%$ \\
\hline
\end{tabular}


Table 7: Tests for Equality of Means

\begin{tabular}{|c|c|c|c|c|c|}
\hline Holding Period & $\begin{array}{l}\text { Value- } \\
\text { Growth } \\
\text { Spread }\end{array}$ & t test & $\begin{array}{c}\text { Test } \\
\text { statisic } t\end{array}$ & $\begin{array}{c}\text { p- } \\
\text { value }\end{array}$ & 95\% Confidence Interval \\
\hline \multirow[t]{2}{*}{ Quarterly } & $8.52 \%$ & $\begin{array}{l}\text { Pooled- } \\
\text { variance }\end{array}$ & 8.38 & 0.000 & $(0.0650,0.1055)$ \\
\hline & & $\begin{array}{l}\text { Separate- } \\
\text { variance }\end{array}$ & 8.38 & 0.000 & $(0.0650,0.1055)$ \\
\hline \multirow[t]{2}{*}{3 Years } & $138.65 \%$ & $\begin{array}{l}\text { Pooled- } \\
\text { variance }\end{array}$ & 7.41 & 0.000 & $(1.0119,1.7611)$ \\
\hline & & $\begin{array}{l}\text { Separate- } \\
\text { variance }\end{array}$ & 7.41 & 0.000 & $(1.0072,1.7657)$ \\
\hline \multirow[t]{2}{*}{5 Years } & $214.54 \%$ & $\begin{array}{l}\text { Pooled- } \\
\text { variance }\end{array}$ & 10.24 & 0.000 & $(1.7218,2.5689)$ \\
\hline & & $\begin{array}{l}\text { Separate- } \\
\text { variance }\end{array}$ & 10.24 & 0.000 & $(1.7174,2.5734)$ \\
\hline \multirow[t]{2}{*}{ Entire Period } & $695.02 \%$ & $\begin{array}{l}\text { Pooled- } \\
\text { variance }\end{array}$ & 6.15 & 0.000 & $(3.1336,6.1332)$ \\
\hline & & $\begin{array}{c}\text { Separate- } \\
\text { variance }\end{array}$ & 6.15 & 0.000 & $(3.1108,6.1560)$ \\
\hline
\end{tabular}

Table 8a: Four States of the World

\begin{tabular}{|c|c|c|c|c|c|c|c|}
\hline Period & Classification & Period & Classification & Period & Classification & Period & Classification \\
\hline $\begin{array}{c}94 Q 2- \\
94 Q 3\end{array}$ & NW10 & $\begin{array}{c}\text { 96Q4 - } \\
\text { 97Q1 }\end{array}$ & NB10 & $\begin{array}{c}99 Q 2- \\
99 Q 3\end{array}$ & NW10 & $\begin{array}{c}\text { 01Q4 - } \\
02 Q 1\end{array}$ & NB10 \\
\hline $\begin{array}{c}94 Q 3- \\
94 Q 4\end{array}$ & NB10 & $\begin{array}{c}97 Q 1- \\
97 Q 2\end{array}$ & NW10 & $\begin{array}{c}\text { 99Q3 - } \\
\text { 99Q4 }\end{array}$ & W10 & $\begin{array}{c}02 Q 1- \\
02 Q 2\end{array}$ & NB10 \\
\hline $\begin{array}{c}\text { 94Q4 - } \\
\text { 95Q1 }\end{array}$ & W10 & $\begin{array}{c}\text { 97Q2 - } \\
\text { 97Q3 }\end{array}$ & B10 & $\begin{array}{c}\text { 99Q4 - } \\
\text { 00Q1 }\end{array}$ & B10 & $\begin{array}{c}\text { 02Q2 - } \\
02 Q 3\end{array}$ & W10 \\
\hline $\begin{array}{c}95 Q 1- \\
95 Q 2\end{array}$ & B10 & $\begin{array}{c}\text { 97Q3 - } \\
\text { 97Q4 }\end{array}$ & W10 & $\begin{array}{c}00 Q 1- \\
\text { 00Q2 }\end{array}$ & W10 & $\begin{array}{c}\text { 02Q3 - } \\
02 Q 4\end{array}$ & NW10 \\
\hline $\begin{array}{c}\text { 95Q2 - } \\
\text { 95Q3 }\end{array}$ & NB10 & $\begin{array}{c}\text { 97Q4 - } \\
98 \mathrm{1}\end{array}$ & W10 & $\begin{array}{c}\text { 00Q2 - } \\
00 Q 3\end{array}$ & NB10 & $\begin{array}{c}02 \mathrm{Q} 4 \text { - } \\
03 \mathrm{Q} 1\end{array}$ & NW10 \\
\hline $\begin{array}{c}95 Q 3- \\
95 Q 4\end{array}$ & NW10 & $\begin{array}{c}\text { 98Q1 - } \\
98 \mathrm{2}\end{array}$ & B10 & $\begin{array}{c}00 Q 3- \\
00 Q 4\end{array}$ & NW10 & $\begin{array}{c}\text { 03Q1 - } \\
\text { 03Q2 }\end{array}$ & W10 \\
\hline $\begin{array}{c}\text { 95Q4 - } \\
96 \mathrm{1}\end{array}$ & B10 & $\begin{array}{c}98 \mathrm{Q} 2- \\
98 \mathrm{Q} 3\end{array}$ & W10 & $\begin{array}{c}\text { 00Q4 - } \\
01 \mathrm{Q} 1\end{array}$ & NB10 & $\begin{array}{c}\text { 03Q2 - } \\
03 Q 3\end{array}$ & B10 \\
\hline $\begin{array}{c}96 \mathrm{Q} 1- \\
96 \mathrm{2} 2\end{array}$ & NB10 & $\begin{array}{c}98 Q 3- \\
98 Q 4\end{array}$ & B10 & $\begin{array}{c}\text { 01Q1 - } \\
01 \mathrm{Q}\end{array}$ & W10 & $\begin{array}{c}\text { 03Q3 - } \\
\text { 03Q4 }\end{array}$ & B10 \\
\hline $\begin{array}{c}\text { 96Q2 - } \\
\text { 96Q3 }\end{array}$ & NW10 & $\begin{array}{c}\text { 98Q4 - } \\
99 \mathrm{1}\end{array}$ & NB10 & $\begin{array}{c}\text { 01Q2 - } \\
\text { 01Q3 }\end{array}$ & NW10 & $\begin{array}{c}\text { 03Q4 - } \\
\text { 04Q1 }\end{array}$ & B10 \\
\hline $\begin{array}{c}96 Q 3- \\
96 Q 4\end{array}$ & NB10 & $\begin{array}{c}99 Q 1- \\
\text { 99Q2 }\end{array}$ & B10 & $\begin{array}{c}\text { 01Q3 - } \\
\text { 01Q4 }\end{array}$ & W10 & $\begin{array}{c}\text { 04Q1 - } \\
\text { 04Q2 }\end{array}$ & NW10 \\
\hline
\end{tabular}




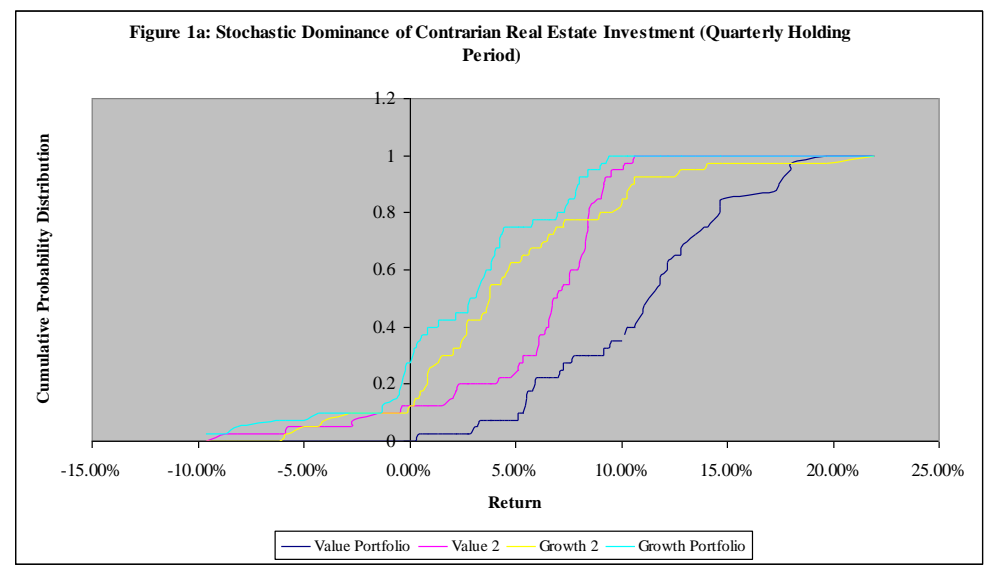

Figure 1c: Stochastic Dominance Analysis of Contrarian Real Estate Investment (5-Year Holding Period)

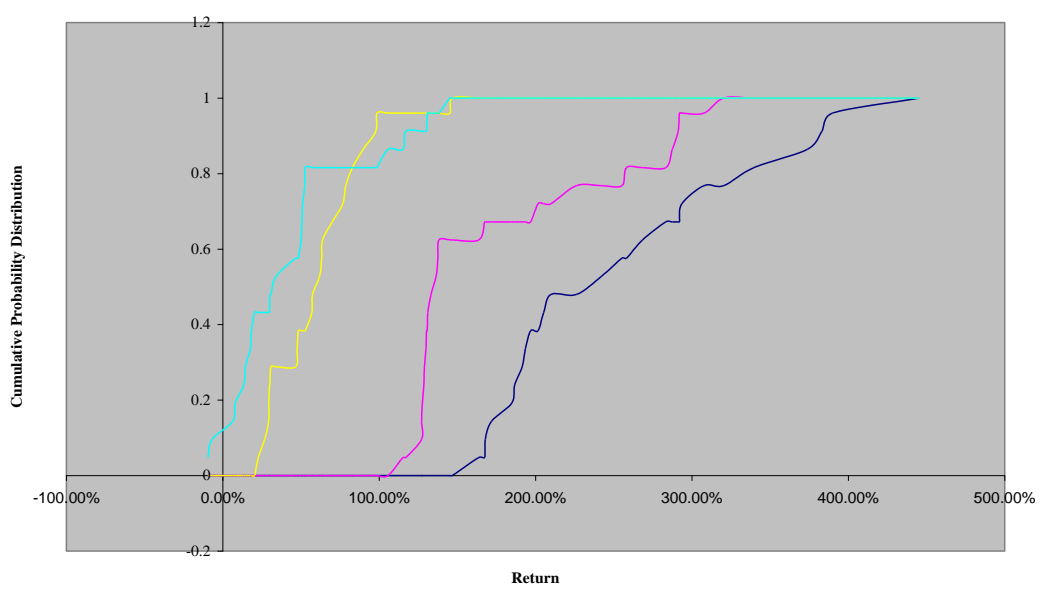

- Value Portfolio - Value 2-Growh 2 - Growh Portfolio

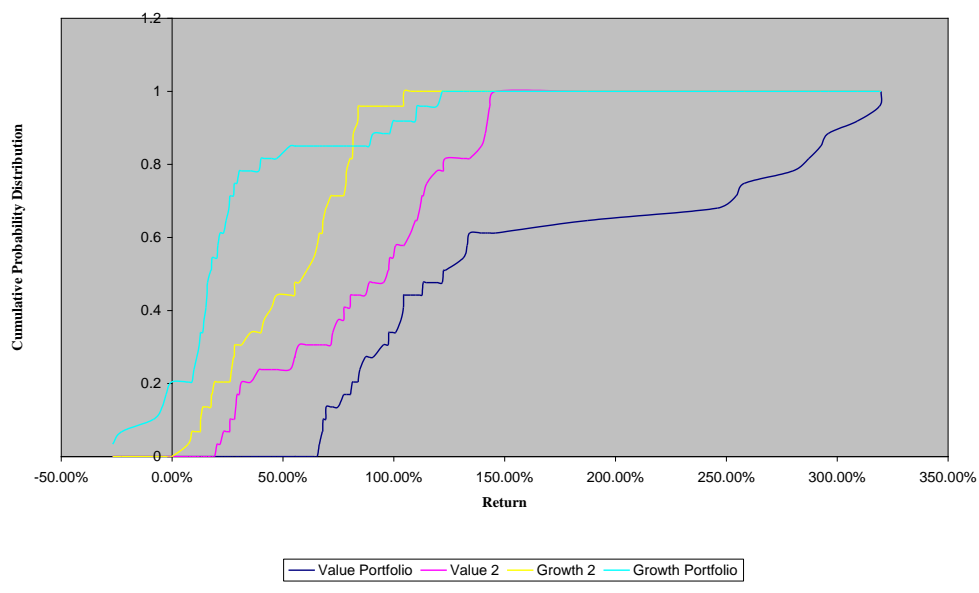

Figure 1d:Stochastic Dominance Analysis of Contrarian Real Estate Investment (>=5-Year Holding Period)

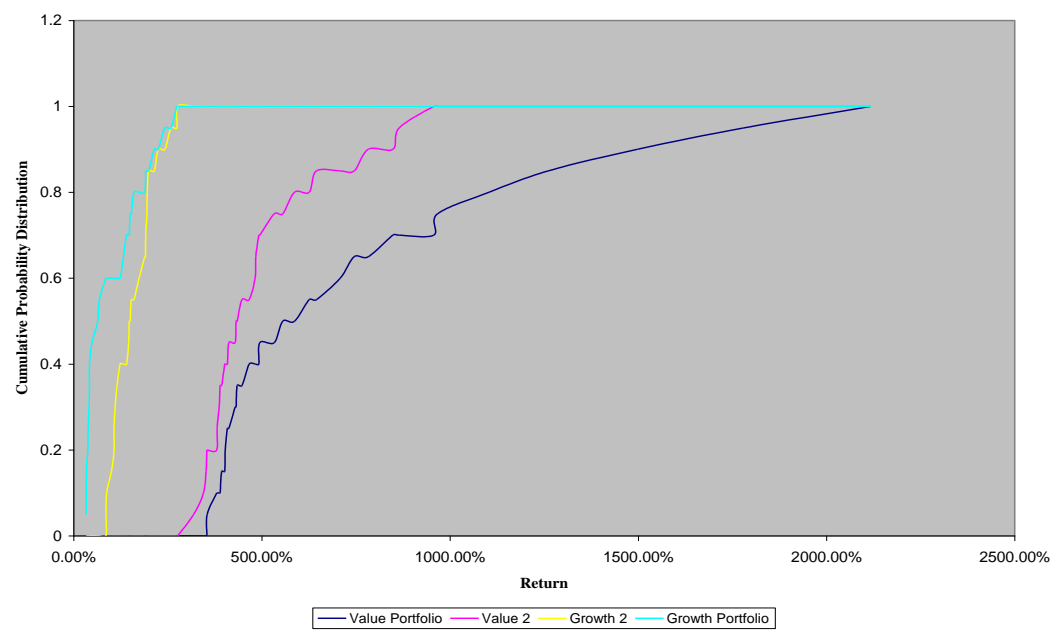




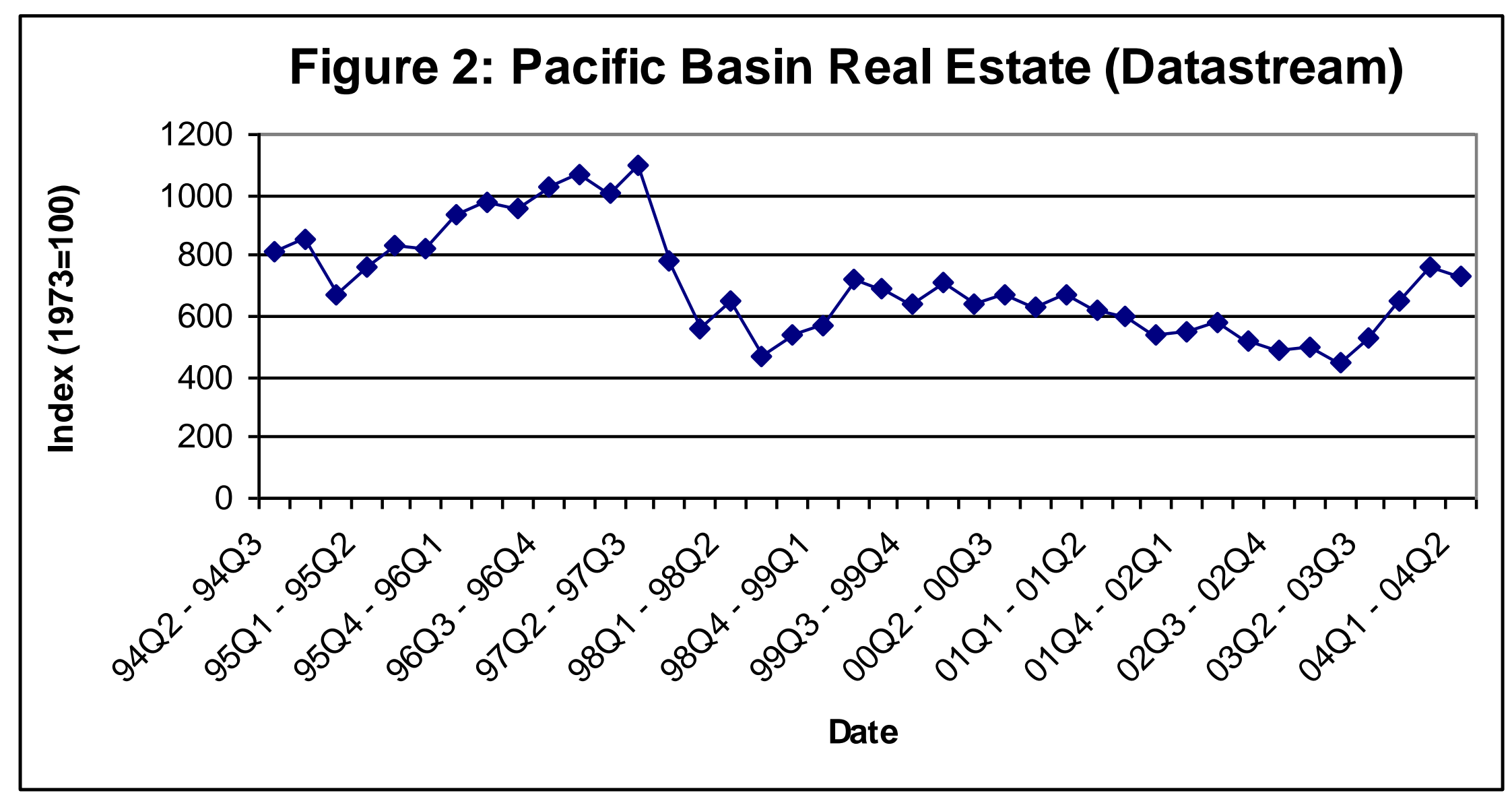


Table 8b: Performance of Portfolios in Best and Worst Times

\begin{tabular}{|c|c|c|c|c|c|c|}
\cline { 5 - 8 } & Value & Growth & Spread & t test & Test statistic t & $\begin{array}{c}\text { p- } \\
\text { value }\end{array}$ \\
\hline Worst 10 quarters & $10.83 \%$ & $1.14 \%$ & $9.69 \%$ & Pooled-variance & 4.92 & 0.000 \\
\hline Next Worst 10 Quarters & $11.81 \%$ & $3.66 \%$ & $8.16 \%$ & Pooled-variance & 4.92 & 0.000 \\
\hline & & & & Separate-variance & 4.34 & 0.000 \\
\hline Next Best 10 Quarters & $11.54 \%$ & $3.38 \%$ & $8.16 \%$ & Pooled-variance & 3.34 & 0.001 \\
\hline & & & & Separate-variance & 3.34 & 0.004 \\
\hline Best 10 Quarters & $9.57 \%$ & $1.48 \%$ & $8.09 \%$ & Pooled-variance & 4.23 & 0.001 \\
\hline & & & & Separate-variance & 4.23 & 0.001 \\
\hline
\end{tabular}

Table 9: Test for Equality of Variances

\begin{tabular}{|c|c|c|c|c|c|c|}
\hline \multirow{2}{*}{ Holding Period } & \multirow{2}{*}{$\begin{array}{c}\text { Test } \\
\text { statistics }\end{array}$} & \multirow{2}{*}{$\begin{array}{c}\mathbf{p}- \\
\text { value }\end{array}$} & \multicolumn{2}{|c|}{ 95\% Bonferroni confidence intervals } & \multicolumn{2}{|c|}{ Decision } \\
\cline { 4 - 7 } & & Value & Growth & $\mathbf{\alpha = 0 . 0 5}$ & $\mathbf{\alpha}=\mathbf{0 . 0 1}$ \\
\hline Quarterly & 0.12 & 0.732 & $(0.0368,0.0616)$ & $(0.0357,0.0597)$ & $\begin{array}{c}\text { Do not } \\
\text { reject }\end{array}$ & $\begin{array}{c}\text { Do not } \\
\text { reject }\end{array}$ \\
\hline 3 Years & 15.33 & 0.000 & $(0.7217,1.3298)$ & $(0.2800,0.5158)$ & Reject & Reject \\
\hline 5 Years & 8.46 & 0.006 & $(0.6283,1.3022)$ & $(0.3272,0.6781)$ & Reject & Reject \\
\hline Entire Period & 21.76 & 0.000 & $(3.7598,6.2919)$ & $(0.5298,0.8865)$ & Reject & Reject \\
\hline
\end{tabular}

Table 10: Coefficient of Variation

\begin{tabular}{|c|c|c|c|c|c|}
\hline Holding Period & $\begin{array}{c}\text { Quartile } \\
\text { Portfolio }\end{array}$ & $\begin{array}{c}\text { Standard } \\
\text { deviation }\end{array}$ & $\begin{array}{c}\text { Mean } \\
\text { Return }\end{array}$ & $\begin{array}{c}\text { Coefficient of } \\
\text { Variation }\end{array}$ & $\begin{array}{c}\text { Return to } \\
\text { Risk }\end{array}$ \\
\hline Quarterly & Value & $4.62 \%$ & $10.94 \%$ & 0.42 & 2.37 \\
\hline & Growth & $4.48 \%$ & $2.41 \%$ & 1.86 & 0.54 \\
\hline 3 Years & Value & $93.88 \%$ & $165.24 \%$ & 0.57 & 1.76 \\
\hline & Growth & $36.42 \%$ & $26.59 \%$ & 1.37 & 0.73 \\
\hline 5 Years & Value & $85.17 \%$ & $259.71 \%$ & 0.33 & 3.05 \\
\hline & Growth & $44.36 \%$ & $45.17 \%$ & 0.98 & 1.02 \\
\hline Entire Period & Value & $510.25 \%$ & $798.41 \%$ & 0.64 & 1.56 \\
\hline & Growth & $78.41 \%$ & $103.39 \%$ & 0.76 & 1.32 \\
\hline
\end{tabular}


Table 11: Initial Yields, Past Performance, and Future Performance of Value and Glamour Properties

\begin{tabular}{|c|c|c|c|c|}
\hline \multicolumn{5}{|c|}{ Panel A: Initial Yields } \\
\hline & & & Value & Growth \\
\hline 1999 & $\begin{array}{l}\text { Q1- } \\
\text { Q2 }\end{array}$ & Initial Yield & 0.1005 & 0.0400 \\
\hline \multirow{4}{*}{1999} & \multirow{4}{*}{$\begin{array}{l}\text { Q2- } \\
\text { Q3 }\end{array}$} & \multirow{4}{*}{$\begin{array}{c}\text { Portfolio } \\
\text { Composition }\end{array}$} & Bangkok CBD & Auckland CBD \\
\hline & & & Jakarta CBD & Raffles Place \\
\hline & & & KLCC & Shenton Way \\
\hline & & & Makati CBD & Tokyo CBD \\
\hline
\end{tabular}

\begin{tabular}{|c|c|c|c|c|c|}
\hline \multicolumn{6}{|c|}{ Panel B: Past Performance } \\
\hline & & \multicolumn{2}{|c|}{ Value } & \multicolumn{2}{|c|}{ Growth } \\
\hline & & $\begin{array}{l}\text { Capital } \\
\text { Growth }\end{array}$ & $\begin{array}{l}\text { Rental } \\
\text { Growth }\end{array}$ & $\begin{array}{l}\text { Capital } \\
\text { Growth }\end{array}$ & $\begin{array}{l}\text { Rental } \\
\text { Growth }\end{array}$ \\
\hline \multirow[t]{2}{*}{1994} & Q3 & $2.49 \%$ & $1.29 \%$ & $6.60 \%$ & $9.65 \%$ \\
\hline & Q4 & $2.26 \%$ & $0.79 \%$ & $6.33 \%$ & $8.37 \%$ \\
\hline \multirow[t]{4}{*}{1995} & Q1 & $2.14 \%$ & $0.68 \%$ & $5.13 \%$ & $7.66 \%$ \\
\hline & Q2 & $0.00 \%$ & $1.03 \%$ & $2.41 \%$ & $5.30 \%$ \\
\hline & Q3 & $-0.05 \%$ & $1.28 \%$ & $2.85 \%$ & $5.38 \%$ \\
\hline & Q4 & $-0.03 \%$ & $0.89 \%$ & $3.30 \%$ & $5.04 \%$ \\
\hline \multirow[t]{4}{*}{1996} & Q1 & $-0.07 \%$ & $0.98 \%$ & $2.90 \%$ & $4.59 \%$ \\
\hline & Q2 & $-0.42 \%$ & $-0.72 \%$ & $2.74 \%$ & $2.27 \%$ \\
\hline & Q3 & $-0.47 \%$ & $-0.78 \%$ & $2.62 \%$ & $2.46 \%$ \\
\hline & Q4 & $-0.56 \%$ & $-1.19 \%$ & $2.51 \%$ & $2.38 \%$ \\
\hline \multirow[t]{4}{*}{1997} & Q1 & $-0.61 \%$ & $-0.91 \%$ & $2.66 \%$ & $2.35 \%$ \\
\hline & Q2 & $-7.88 \%$ & $-6.58 \%$ & $-2.39 \%$ & $-3.39 \%$ \\
\hline & Q3 & $-8.92 \%$ & $-7.12 \%$ & $-2.58 \%$ & $-3.64 \%$ \\
\hline & Q4 & $-10.38 \%$ & $-8.32 \%$ & $-2.77 \%$ & $-3.98 \%$ \\
\hline \multirow[t]{4}{*}{1998} & Q1 & $-12.58 \%$ & $-9.88 \%$ & $-2.91 \%$ & $-4.20 \%$ \\
\hline & Q2 & $-5.34 \%$ & $-4.35 \%$ & $-4.84 \%$ & $-2.41 \%$ \\
\hline & Q3 & $-6.17 \%$ & $-5.19 \%$ & $-5.87 \%$ & $-2.74 \%$ \\
\hline & Q4 & $-7.21 \%$ & $-5.30 \%$ & $-7.06 \%$ & $-3.10 \%$ \\
\hline \multirow[t]{2}{*}{1999} & Q1 & $-8.95 \%$ & $-6.44 \%$ & $-8.10 \%$ & $-3.39 \%$ \\
\hline & Q2 & $-0.43 \%$ & $-2.87 \%$ & $-0.11 \%$ & $0.26 \%$ \\
\hline \multicolumn{6}{|c|}{ Geometric } \\
\hline \multicolumn{2}{|c|}{$\begin{array}{c}\text { Average } \\
\text { Growth } \\
\text { Rate }\end{array}$} & $-3.27 \%$ & $0 \%$ & $0.08 \%$ & $1.35 \%$ \\
\hline
\end{tabular}


Table 11: Fundamental Variables, Past

Performance, and Future Performance of Value and Glamour Properties

\begin{tabular}{|c|c|c|c|c|c|}
\hline \multicolumn{6}{|c|}{ "Panel C: Future Performance } \\
\hline & & \multicolumn{2}{|c|}{ Value } & \multicolumn{2}{|c|}{ Growth } \\
\hline & & $\begin{array}{l}\text { Capital } \\
\text { Growth }\end{array}$ & $\begin{array}{l}\text { Rental } \\
\text { Growth }\end{array}$ & $\begin{array}{l}\text { Capital } \\
\text { Growth }\end{array}$ & $\begin{array}{l}\text { Rental } \\
\text { Growth }\end{array}$ \\
\hline \multirow[t]{2}{*}{1999} & Q3 & $-0.47 \%$ & $-2.93 \%$ & $-0.33 \%$ & $0.33 \%$ \\
\hline & Q4 & $-0.58 \%$ & $-3.11 \%$ & $-0.56 \%$ & $0.18 \%$ \\
\hline \multirow[t]{4}{*}{2000} & Q1 & $-0.62 \%$ & $-3.71 \%$ & $-0.66 \%$ & $0.07 \%$ \\
\hline & Q2 & $-1.52 \%$ & $-1.55 \%$ & $-1.48 \%$ & $6.03 \%$ \\
\hline & Q3 & $-2.67 \%$ & $-3.05 \%$ & $-1.36 \%$ & $5.57 \%$ \\
\hline & Q4 & $-4.25 \%$ & $-5.93 \%$ & $-1.24 \%$ & $5.20 \%$ \\
\hline \multirow[t]{4}{*}{2001} & Q1 & $-3.39 \%$ & $-4.07 \%$ & $-0.71 \%$ & $4.81 \%$ \\
\hline & Q2 & $-2.28 \%$ & $-1.93 \%$ & $-4.75 \%$ & $-2.28 \%$ \\
\hline & Q3 & $-2.64 \%$ & $-4.41 \%$ & $-4.69 \%$ & $-2.45 \%$ \\
\hline & Q4 & $0.39 \%$ & $-0.06 \%$ & $-4.98 \%$ & $-2.95 \%$ \\
\hline \multirow[t]{4}{*}{2002} & Q1 & $-0.82 \%$ & $-0.48 \%$ & $-5.40 \%$ & $-3.28 \%$ \\
\hline & Q2 & $0.40 \%$ & $-1.20 \%$ & $-2.78 \%$ & $-1.26 \%$ \\
\hline & Q3 & $1.00 \%$ & $-1.04 \%$ & $-1.16 \%$ & $-0.90 \%$ \\
\hline & Q4 & $-1.97 \%$ & $-2.53 \%$ & $-2.79 \%$ & $-2.33 \%$ \\
\hline \multirow[t]{4}{*}{2003} & Q1 & $0.53 \%$ & $0.10 \%$ & $-1.64 \%$ & $-1.17 \%$ \\
\hline & Q2 & $0.54 \%$ & $-0.36 \%$ & $-3.39 \%$ & $-3.32 \%$ \\
\hline & Q3 & $2.38 \%$ & $1.64 \%$ & $-4.29 \%$ & $-5.47 \%$ \\
\hline & Q4 & $2.72 \%$ & $1.89 \%$ & $1.07 \%$ & $-0.75 \%$ \\
\hline \multirow[t]{2}{*}{2004} & Q1 & $1.69 \%$ & $0.48 \%$ & $1.96 \%$ & $1.71 \%$ \\
\hline & Q2 & $3.50 \%$ & $2.40 \%$ & $2.02 \%$ & $2.02 \%$ \\
\hline \multicolumn{6}{|c|}{ Geometric } \\
\hline \multicolumn{2}{|c|}{$\begin{array}{l}\text { Average } \\
\text { Growth } \\
\text { Rate }\end{array}$} & $-0.42 \%$ & $-1.52 \%$ & $-1.88 \%$ & $-0.06 \%$ \\
\hline
\end{tabular}

Table 12: Growth of Rental Income Per Dollar (2nd Quarter $1999=$ Year 0)

\begin{tabular}{|c|c|c|c|c|c|}
\hline Year & $\begin{array}{c}\text { Growth } \\
\text { Portfolio }\end{array}$ & $\begin{array}{c}\text { Value } \\
\text { Portfolio }\end{array}$ & Year & $\begin{array}{c}\text { Growth } \\
\text { Portfolio }\end{array}$ & $\begin{array}{c}\text { Value } \\
\text { Portfolio }\end{array}$ \\
\hline $\mathbf{0}$ & 0.0400 & 0.1005 & $\mathbf{1 3}$ & 0.0476 & 0.0704 \\
\hline $\mathbf{1}$ & 0.0405 & 0.0978 & $\mathbf{1 4}$ & 0.0483 & 0.0685 \\
\hline $\mathbf{2}$ & 0.0411 & 0.0951 & $\mathbf{1 5}$ & 0.0489 & 0.0667 \\
\hline $\mathbf{3}$ & 0.0416 & 0.0926 & $\mathbf{1 6}$ & 0.0496 & 0.0649 \\
\hline $\mathbf{4}$ & 0.0422 & 0.0901 & $\mathbf{1 7}$ & 0.0502 & 0.0631 \\
\hline $\mathbf{5}$ & 0.0428 & 0.0876 & $\mathbf{1 8}$ & 0.0509 & 0.0614 \\
\hline $\mathbf{6}$ & 0.0434 & 0.0853 & $\mathbf{1 9}$ & 0.0516 & 0.0597 \\
\hline $\mathbf{7}$ & 0.0439 & 0.0830 & $\mathbf{2 0}$ & 0.0523 & 0.0581 \\
\hline $\mathbf{8}$ & 0.0445 & 0.0807 & $\mathbf{2 1}$ & 0.0530 & 0.0566 \\
\hline $\mathbf{9}$ & 0.0451 & 0.0786 & $\mathbf{2 2}$ & 0.0537 & 0.0550 \\
\hline $\mathbf{1 0}$ & 0.0457 & 0.0764 & $\mathbf{2 3}$ & 0.0545 & 0.0536 \\
\hline $\mathbf{1 1}$ & 0.0464 & 0.0744 & & & \\
\hline $\mathbf{1 2}$ & 0.0470 & 0.0724 & & & \\
\hline
\end{tabular}

